\title{
PENGARUH PERTUMBUHAN PENJUALAN, UKURAN PERUSAHAAN, STRUKTUR ASET DAN \\ PROFITABILITAS TERHADAP STRUKTUR MODAL PADA PERUSAHAAN MANUFAKTUR YANG TERDAFTAR DI BURSA EFEK INDONESIA PERIODE TAHUN 2012-2015
}

\author{
Nelli Novyarni ${ }^{1}$ dan Lisna Wati ${ }^{2}$ \\ Sekolah Tinggi Ilmu Ekonomi Indonesia \\ ${ }^{1}$ sweetynovyarni@gmail.com \\ 2diandralisna@gmail.com
}

\begin{abstract}
Capital structure is the ratio or the balance between foreign capital and equity capital that affect decision making employment decisions. Where the capital structure is influenced by sales growth, company size, structure and profitability of assets. This study aims to influence sales growth, company size, structure and profitability of assets partially and simultaneously the capital structure on companies listed on the Stock Exchange. The research strategy used in this study is a research strategy associative. The method of research used in this research is quantitative method. In this study population was used as the financial statements of companies listed on the Stock Exchange. Samples taken by the researchers was 35 manufacturing companies that go public in BEI using data from the financial statements of the balance sheet and income statement in the period 2012-2015. The analytical tool used is Eviews 9.0. Based on the analysis and discussion show sales growth and no significant effect on the capital structure on companies listed on the Stock Exchange. The size of the company and significant effect on the capital structure of companies listed on the Stock Exchange. The structure of assets and significant effect on the capital structur e of companies listed on the Stock Exchange. Profitability and no significant effect on the capital structure on companies listed on the Stock Exchange. Based on the results of simultaneous hypothesis testing the rate of sales growth, company size, structure and profitability of assets simultaneously significantly affect the capital structure means the hypothesis is proved significant.
\end{abstract}

Keywords: Sales Growth, Company Size, Structure of assets, profitability, capital structure

\section{PENDAHULUAN}

Struktur modal adalah perbandingan atau perimbangan antara modal asing dengan modal sendiri. Modal asing adalah modal yang berasal dari luar perusahaan yang sifatnya sementara bekerja di dalam perusahaan dan bagi perusahaan yang bersangkutan modal tersebut merupakan hutang yang pada saatnya harus dibayar kembali. Modal asing digolongkan menjadi 3 berdasarkan jangka waktunya, yaitu modal asing jangka pendek, jangka menengah dan jangka 
panjang. Sedangkan modal sendiri adalah modal yang berasal dari pemilik perusahaan yang tertanam di perusahaan untuk jangka waktu tertentu (Riyanto, 2010:14)

Struktur modal (capital structure) sangat penting dalam membiayai aktifitas operasional perusahaan. Besarnya struktur modal sangat tergantung dari komposisi sumber daya yang diperoleh dari pihak eksternal maupun internal perusahaan, yang berupa hutang dan modal sendiri. Makin besar modal yang disetorkan oleh pemegang saham, makin leluasa bagi manajemen untuk kebutuhan operasionalnya, sebab tidak ada kewajiban kepada kreditor. Komponen modal sendiri atau equity pada perusahaan yang berbentuk Perseroan Terbatas (PT) antara lain berupa modal disetor, agio saham, laba ditahan dan laba tahun berjalan. Keinginan untuk mewujudkan struktur modal yang optimal sudah menjadi perhatian para praktisi dan akademisi. Rasio antara sumber dana dari pihak ketiga terhadap ekuitas disebut debt to equity ratio $(D E R)$. Rasio ini dapat menunjukkan tingkat risiko suatu perusahaan dimana semakin tinggi $D E R$, maka semakin tinggi risiko perusahaan, karena pendanaan (financing) dari hutang semakin besar. Investor cenderung lebih tertarik pada tingkat $D E R$ tertentu yang besarnya kurang dari satu, karena jika lebih besar dari satu menunjukkan risiko perusahaan yang lebih tinggi (Sartono, 2011:225).

Perusahaan dalam melakukan financing yang berkaitan dengan modal sendiri (equity) harus memperhatikan dua hal, (1) Apabila perusahan ingin mempertahankan posisi solvabilitas dan likuiditas diperlukan modal sendiri yang memadai, (2) pertumbuhan modal sendiri yang berlebihan dapat menurunkan rentabilitas modal sendiri dan juga akan meningkatkan biaya modal sendiri. Kenaikan DER sampai tingkat tertentu akan meminimumkan biaya modal, tapi bila pertambahan terlalu berlebihan justru akan berakibat meningkatnya biaya modal yang berupa biaya bunga (Sartono, 2011:226).

Ada fenomena menarik terkait penggunaan hutang di perusahaanperusahaan Indonesia, yaitu adanya tingkat hutang yang tinggi. Tingkat hutang pada perusahaan publik yang terdaftar di BEI selama satu dekade terakhirmenunjukkan bahwa komposisi struktur modal lebih banyak didominasi oleh hutang dengan tingkat leverage di atas 60\%. Fenomena yang terjadi di perusahaan Indonesia ini menggambarkan bahwa dalam jangka panjang pendanaan perusahaan untuk aktivitas operasi sangat tergantung dengan hutang, kondisi yang tidak cukup bagus ketika ekonomi sedang turun, tentu akan memiliki resiko likuiditas yang besar bagi perusahaan. Mengingat kondisi ekonomi yang selalu mengalami perubahan, maka dapat mempengaruhi kondisi perusahaan yang dapat dilihat dari labanya. Laba perusahaan yang harusnya meningkat, justru sebaliknya mengalami penurunan. Di pasar saham, perusahaan yang telah go publik dikelompokkan ke dalam beberapa sektor industri. Pengelompokkan tersebut, sektor industri manufaktur memiliki jumlah perusahaan yang paling besar, merupakan industri yang bergerak menghasilkan barang dan jasa yang bukan tergolong produk primer dan merupakan emiten terbesar dibanding industri lain.

Perkembangan industri manufaktur cukup pesat, hal ini dapat dilihat dari perkembangan perusahaan manufaktur yang terdaftar di BEI dari tahun ke tahunnya semakin bertambah, maka tidak menutup kemungkinan perusahaan ini sangat dibutuhkan oleh masyarakat dan prospeknya akan menguntungkan di masa 
kini maupun di masa yang akan datang. Saat ini persaingan di industri manufaktur semakin ketat, karena banyaknya produk impor yang sangat mudah masuk ke pasar.

Perusahaan manufaktur yang terdaftar di BEI meliputi: sektor industri dasar dan kimia, sektor aneka industri, serta sektor industri barang konsumsi. Salah satu sektor industri manufaktur yang mengalami pertumbuhan positif adalah sektor industri dasar dan kimia. Hal ini dapat dilihat dari peningkatan jumlah emiten sektor industri dasar dan kimia yang jauh lebih besar dibandingkan sektor lainnya. Tabel 1 memperlihatkan jumlah emiten perusahaan manufaktur per sektor di BEI.

Tabel 1. Perkembangan Jumlah Perusahaan Manufaktur yang Terdaftar di BEI Periode Tahun 2012-2015

\begin{tabular}{llcccc}
\multirow{2}{*}{ No } & \multicolumn{1}{c}{ Jenis Usaha } & $\mathbf{2 0 1 2}$ & $\mathbf{2 0 1 3}$ & $\mathbf{2 0 1 4}$ & $\mathbf{2 0 1 5}$ \\
\hline 1 & Sektor Industri Dasar dan Kimia & 60 & 62 & 63 & 65 \\
2 & Sektor Aneka Industri & 38 & 42 & 42 & 41 \\
3 & Sektor Industri Barang Konsumsi & 33 & 35 & 36 & 37 \\
\multirow{2}{*}{ Jumlah } & 131 & 139 & 141 & 143 \\
& \multicolumn{5}{c}{ Sumber : Bursa Efek Indonesia }
\end{tabular}

Berdasarkan data dari Jakarta Stock Exchange (JSX) tahun 2012-2015 berturut-turut jumlah emiten perusahaan manufaktur mengalami kenaikan dari 132 menjadi 143 perusahaan, kemudian dari perusahaan-perusahaan tersebut dibagi menjadi tiga kelompok/sektor yang terdiri dari industri dasar dan kimia, industri barang konsumsi, dan aneka industri. (www.idx.co.id). Persaingan industri manufaktur yang terdaftar di Indonesia semakin ketat, hal ini dapat dilihat dari jumlah perusahaan manufaktur yang terdaftar di Bursa Efek Indonesia (BEI) dari periode ke periodenya semakin bertambah. Selain itu, semakin ketatnya persaingan industri manufaktur yang terdaftar ditandai dengan banyaknya produk impor dan produk ilegal yang dengan mudahnya masuk ke pasar Indonesia sehingga menjadi hambatan bagi perusahaan manufaktur yang terdaftar di Indonesia untuk menguasai pasar. Daya saing produk manufaktur semakin melemah. Di dalam negeri, produk manufaktur seperti elektronika rumah tangga kalah bersaing dengan produk impor, apalagi diperburuk dengan banyaknya produk ilegal. Di pasar internasional, produk tekstil dan produk kayu yang masih menjadi primadona ekspor kalah bersaing dengan produk dari Cina dan negara ASEAN lainnya. (sumber: fiskal.depkeu.go.id).

Berdasarkan uraian di atas, maka penelitian ini berjudul "PENGARUH Pertumbuhan Penjualan, Ukuran Perusahaan, Struktur Aset dan Profitabilitas Terhadap Struktur Modal yang Terdaftar di Bursa Efek Indonesia."

\section{KAJIAN LITERATUR}

\subsection{Struktur Modal}

Sartono (2011:225) menyatakan, "Struktur modal merupakan perimbangan jumlah utang jangka pendek yang bersifat permanen, utang jangka panjang, saham preferen dan saham biasa." Sedangkan menurut Besley \& Brigham (2012:205), "Struktur modal diukur dengan membandingkan total hutang dengan total asset, 
yang mencerminkan besarnya pandanaan melalui hutang baik hutang lancar maupun hutang jangka penjang terhadap asset secara keseluruhan".

Struktur Modal mengindikasikan bagaimana perusahaan membiayai kegiatan operasionalnya atau bagaimana perusahaan membiayai asetnya. Riyanto (2010:15) mengatakan bahwa "Struktur finansial mencerminkan cara bagaimana aset-aset perusahaan, dengan demikian struktur finansial tercermin pada keseluruhan pasiva dalam neraca. Struktur finansial mencerminkan pula perimbangan antara keseluruhan modal asing (baik jangka pendek maupun jangka panjang) dengan jumlah modal sendiri". Struktur modal merupakan perbandingan antara hutang (modal asing) dengan ekuitas (modal sendiri).

Weston dan Copeland (2010:3) mengatakan bahwa "Struktur keuangan adalah cara bagaimana perusahaan membiayai asetnya. Struktur keuangan dapat dilihat pada seluruh sisi kanan dari neraca. Ini terdiri dari hutang jangka pendek, hutang jangka panjang dan modal pemegang saham". Struktur modal adalah perimbangan atau perbandingan antara jumlah hutang jangka panjang dengan modal sendiri (Riyanto, 2010:282). Pendapat lain mengatakan bahwa struktur modal merupakan perimbangan jumlah hutang jangka pendek yang bersifat permanen, hutang jangka panjang, saham preferen, dan saham biasa (Sartono, 2011:225). Berdasarkan beberapa pendapat tersebut, pada dasarnya struktur modal yaitu pembiayaan perusahaan yang bersifat permanen yang terdiri dari hutang jangka panjang, saham biasa dan saham preferen.

Riyanto (2010:283), struktur modal suatu perusahaan secara umum terdiri atas modal sendiri, modal saham, saldo laba dan modal asing. Modal asing / hutang jangka panjang di lain pihak, merupakan sumber dana bagi perusahaan yang harus dibayar kembali dalam jangka waktu tertentu. Semakin lama jangka waktu dan semakin ringannya syarat-syarat pembayaran kembali hutang tersebut akan mempermudah dan memperluas bagi perusahaan untuk memberdayagunakan sumber dana yang berasal dari modal asing / hutang jangka panjang tersebut. Meskipun demikian, hutang tetap harus dibayar kembali pada waktu yang sudah ditetapkan tanpa memperhatikan kondisi finansial perusahaan pada saat itu dan harus sudah disertai dengan bunga yang sudah diperhitungkan sebelumnya. Demikian seandainya perusahaan tidak mampu membayar kembali hutang dan bunganya, maka kreditur dapat memaksa perusahaan dengan menjual aset yang dijadikan jaminannya. Oleh karena itu, kegagalan untuk membayar kembali hutang atau bunganya akan mengakibatkan para pemilik perusahaan kehilangan kontrol terhadap perusahaannya seperti halnya terhadap sebagian atau keseluruhan modalnya yang ditanamkan dalam perusahaan.

Sundjaja (2010 : 270) Komponen Struktur Modal adalah utang jangka panjang dan modal sendiri.

Ada beberapa rasio yang dapat digunakan untuk mengukur struktur modal adalah debt to asset ratio, Debt to Equity Ratio (DER), Long Term Debt to Equity Ratio (LDER) dan Interest Coverage Ratio (ICR)

Penelitian ini struktur modal yang dgunakan adalah debt to equity ratio. Debt to equity ratio menurut Fahmi (2011:75) merupakan perbandingan antara hutang dengan modal yang dimiliki oleh perusahaan untuk menilai batas kemampuan modal tersebut dengan menanggung risiko atas modal pinjaman yang digunakan.

Definisi di atas, debt to equity ratio dapat diartikan sebagai rasio 
pengukuran tingkat pengembalian hutang perusahaan yang digunakan sebagai modal utuk kegiatan perluasan perluasan ataupun membiayai kegiatan operasional perusahaan dengan membagi total hutang dengan ekuitas pemegang saham. Debt to equity ratio ini sendiri dapat mengindikasikan seberapa besar modal dan dan hutang yang digunakan oleh perusahaan untuk membiayai aset-asetnya.

\subsection{Pertumbuhan Penjualan}

Berdasarkan Kamus Besar Ekonomi (2012:157) "Penjualan adalah suatu transaksi yang melibatkan pengiriman atau penyerahan produk, hak, atau jasa dalam pertukaran kas, janji pembayaran, atau yang dapat disamakan dengan uang atau kombinasinya". Yadati dan Wahyudi (2010:52) "Transaksi penjualan barang dagang dalam perusahaan dagang dapat dilakukan baik secara tunai maupun secara kredit, atau sebagaian secara tunai dan sisanya dibayar secara kredit". Secara umum transaksi penjualan yang dilaksanakan dengan dua cara yaitu :

1) Penjualan tunai yaitu penjualan yang dilaksanakan oleh perusahaan dengan cara mewajibkan pembeli melakukan pembayaran harga barang terlebih dahulu sebelum barang diserahkan kepada pembeli oleh perusahaan.

2) Penjualan kredit yaitu penjualan yang dilaksanakan oleh perusahaan dengan cara mengirimkan barang sesuai dengan order yang diterima dari pembeli dan untuk jangka waktu tertentu perusahaan mempunyai tagihan kepada pembeli tersebut.

Higgins (2013:122) "Penjualan adalah penerimaan yang diperoleh dari pengiriman barang dagangan atau dari penyerahan pelayanan dalam bursa sebagi barang pertimbangan yaitu dalam bentuk tunai peralatan kas atau harta lainnya". Berati penjualan adalah suatu perjanjian antara penjualan dan pembeli yang memindahkan hak kepemilikan barang kepada pembeli dengan kompensasi pembayaran uang kepada penjual. Penjualan tidak hanya menyangkut pemindahan kepemilikan atas barang atau jasa, tapi didalamnya juga terhadap pemindahan resiko-resiko yang timbul atas kepemilikan tersebut. Swastha (2012:75), "pertumbuhan atas penjualan merupakan indikator penting dari penerimaan pasar dari produk dan/atau jasa perusahaan tersebut, dimana pendapatan yang dihasilkan dari penjualan akan dapat digunakan untuk mengukur tingkat pertumbuhan penjualan".

Suatu perusahaan dapat dikatakan mengalami pertumbuhan ke arah yang lebih baik jika terdapat peningkatan yang konsisten dalam aktivitas utama operasinya. Jadi, pertumbuhan yang terjadi dalam perusahaan dagang sering dikatakan sebagai tingkat pertumbuhan penjualan. Sedangkan Higgins (2013:44) mengatakan bahwa "growth comes from two sources: increasing volume and rising price. Because off all variable cost, most current assets, and current liabilities have a tendency with sales, so it is a good idea to see the growth based on the sales of the company".

Berdasarkan pernyataan di atas dapat dilihat bahwa tingkat pertumbuhan suatu perusahaan dapat dilihat dari pertambahan volume dan peningkatan harga khususnya dalam hal penjualan karena penjualan merupakan suatu aktivitas yang umumnya dilakukan oleh perusahaan untuk mendapatkan tujuan yang ingin dilakukan oleh perusahaan untuk mendapatkan tujuan yang ingin dicapai yaitu tingkat laba yang diharapkan. Perhitungan tingkat penjualan pada akhir periode dengan penjualan yang dijadikan periode dasar. Apabila nilai perbandingannya 
semakin besar, maka dapat dikatakan bahwa tingkat pertumbuhan penjualan semakin baik.

\subsection{Ukuran Perusahaan}

Sartono (2010:249), perusahaan besar yang sudah well- established akan lebih mudah memperoleh modal di pasar modal dibanding dengan perusahaan kecil. Karena kemudahan akses tersebut berarti perusahaan besar memiliki fleksibilitas yang lebih besar pula. Fahmi (2011:2), semakin baik kualitas laporan keuangan yang disajikan maka akan semakin menyakinkan pihak eksternal dalam melihat kinerja keuangan perusahaan tersebut, yang otomatis tentunya pihakpihak yang berhubungan dengan perusahaan akan merasa puas dalam berbagai urusan dengan perusahaan. Perusahaan selalu menginginkan perolehan laba bersih setelah pajak karena bersifat menambah modal sendiri. Berarti laba bersih dapat diperoleh jika jumlah penjualan lebih besar daripada jumlah biaya operasi. Agar diperoleh laba bersih yang sesuai dengan jumlah yang diinginkan, maka perencanaan dan pengendalian menjadi hal yang sangat penting dilakukan oleh pihak manajemen. Perusahaan yang berada pada pertumbuhan penjualan yang tinggi membutuhkan dukungan modal yang semakin besar, demikian juga sebaliknya, pada perusahaan yang tingkat pertumbuhan penjualannya rendah kebutuhan terhadap modal juga semakin kecil. Akan tetapi, jika dana dari sumber intern sudah tidak mencukupi, maka tidak ada pilihan lain bagi perusahaan untuk menggunakan dana yang berasal dari luar perusahaan, baik utang maupun dengan mengeluarkan saham baru. Perusahaan yang besar cenderung memiliki sumber permodalan yang lebih banyak dan memiliki kemungkinan untuk bangkrut yang lebih kecil, sehingga lebih mampu untuk memenuhi kewajiban finansialnya. Perusahaan besar cenderung memiliki utang atau menggunakan dana eksternal dalam jumlah yang lebih besar.

Riyanto (2012:299-300), suatu perusahaan yang besar yang sahamnya tersebar sangat luas, setiap perluasan modal saham hanya akan mempunyai pengaruh yang kecil terhadap kemungkinan hilangnya atau tergesernya pengendalian dari pihak yang dominan terhadap perusahaan bersangkutan. Dengan demikian, maka perusahaan yang besar akan lebih berani mengeluarkan saham baru dalam memenuhi kebutuhan untuk membiayai pertumbuhan yang didasarkan pada penjualan, dibandingkan dengan perusahaan yang kecil. Sawir (2011:101-102) ukuran perusahaan dinyatakan sebagai determinan dari struktur keuangan dalam hampir setiap studi untuk alasan yang berbeda:

Pertama, ukuran perusahaan dapat menentukan tingkat kemudahan perusahaan memperoleh dana dari pasar modal. Perusahaan kecil umumnya kekurangan akses ke pasar modal yang terorganisir, baik untuk obligasi maupun saham. Meskipun mereka memiliki akses, biaya peluncuran dari penjualan sejumlah kecil sekuritas dapat menjadi penghambat. Jika penerbitan sekuritas dapat dilakukan, sekuritas perusahaan kecil mungkin kurang dapat dipasarkan sehingga membutuhkan penentuan harga sedemikian rupa agar investor mendapatkan hasil yang memberikan return lebih tinggi secara signifikan. Kedua, ukuran perusahaan menentukan kekuatan tawar-menawar dalam kontrak keuangan. Perusahaan besar biasanya dapat memilih pendanaan dari berbagai bentuk hutang, termasuk penawaran spesial yang lebih menguntungkan dibandingkan yang ditawarkan perusahaan kecil. Semakin besar jumlah uang yang 
digunakan, semakin besar kemungkinan kemungkinan pembuatan kontrak yang dirancang sesuai dengan preferensi kedua pihak sebagai ganti dari penggunaan kontrak standar hutang. Ketiga, ada kemungkinan pengaruh skala dalam biaya dan return membuat perusahaan yang lebih besar dapat memperoleh lebih banyak laba. Pada akhirnya, ukuran perusahaan diikuti oleh karakteristik lain yang mempengaruhi struktur keuangan. Karakteristik lain tersebut seperti perusahaan sering tidak mempunyai staf khusus, tidak menggunakan rencana keuangan, dan tidak mengembangkan system akuntansi mereka menjadi suatu sistem manajemen.

Brigham dan Houston (2011:117-119), mengemukakan bahwa Ukuran perusahaan adalah suatu skala dimana dapat diklasifikasikan besar kecil perusahaan menurut berbagai cara, antara lain: total aset, $\log$ size, nilai pasar saham, dan lain-lain. Ukuran perusahaan hanya terbagi dalam 3 kategori yaitu : "perusahaan besar (large firm), perusahaan menengah (medium-size) dan perusahaan kecil (small firm)". Variabel ini diukur dengan rata-rata jumlah nilai kekayaan yang dimiliki suatu perusahaan (total aset). Skala pengukuran yang digunakan adalah skala rasio. Ukuran (size) perusahaan bisa diukur dengan menggunakan total aset, penjualan, atau modal dari perusahaan tersebut. Salah satu tolak ukur yang menunjukkan besar kecilnya perusahaan adalah ukuran aset dari perusahaan tersebut. Perusahaan yang memiliki total aset besar menunjukkan bahwa perusahaan tersebut telah mencapai tahap kedewasaan dimana dalam tahap ini arus kas perusahaan sudah positif dan dianggap memiliki prospek yang baik dalam jangka waktu yang relatif lama, selain itu juga mencerminkan bahwa perusahaan relatif lebih stabil dan lebih mampu menghasilkan laba dibanding perusahaan dengan total asset yang kecil.

Ukuran perusahaan merupakan skala perusahaan yang dilihat dari total aset yang dimiliki oleh perusahaan tersebut. Ukuran perusahaan merupakan salah satu faktor penting dalam penggunaan struktur modal perusahaan. Perusahaan yang memiliki ukuran lebih besar biasanya lebih berpengalaman dalam mengelola struktur pendanaan. Perusahaan besar akan cenderung membutuhkan banyak dana dalam membiayai kegiatan operasionalnya (Gitman, 2011:415).

Diuraikan bahwa ukuran perusahaan yang digunakan adalah total aset dimana dalam pengukurannya dikonversikan dalam logaritma natural $(L n)$.

\subsection{Struktur Aset}

Aktiva atau aset adalah segala sumber daya dan harta yang dimiliki perusahaan untuk digunakan dalam operasinya. Suatu perusahaan pada umumnya memiliki dua jenis aset yaitu aset lancar dan aset tetap. Kedua unsur aset ini akan membentuk struktur aset. Struktur aset suatu perusahaan akan tampak dalam sisi sebelah kiri neraca. Struktur aset juga disebut struktur aset atau struktur kekayaan. Struktur aset atau struktur kekayaan adalah "Perimbangan atau perbandingan baik dalam artian absolut maupun dalam artian relatif antara aset lancar dengan aset tetap" (Riyanto, 2012 : 22). Selanjutnya yang dimaksud dengan artian absolut adalah perbandingan dalam bentuk nominal, sedangkan yang dimaksud dengan artian relatif adalah perbandingan dalam bentuk persentase.

Sangat penting bagi perusahaan untuk menentukan berapa besar alokasi 
untuk masing-masing aset serta bentuk-bentuk aset yang harus dimiliki. Karena hal ini menyangkut seberapa besar dana yang dibutuhkan yang berkaitan langsung dengan tujuan jangka panjang perusahaan. Syamsuddin (2011:9), menjelaskan bahwa: Alokasi untuk masing-masing komponen aset mempunyai pengertian "berapa jumlah rupiah" yang harus dialokasikan untuk masing-masing komponen aset baik dalam aset lancar maupun aset tetap. Sesudah menentukan alokasi untuk kedua macam aset tersebut maka biasanya seorang manajer harus menentukan alokasi optimal untuk masing-masing komponen aset lancar. disamping itu seorang manajer keuangan juga harus menentukan alokasi untuk setiap komponen aset tetap serta umur dari masing-masing komponen tersebut, kapan harus diadakan perbaikan, penggantian dan sebagainya.

Syamsudin (2011:9) struktur aset adalah "Penentuan berapa besar alokasi dana untuk masing-masing komponen aset, baik dalam aset lancar maupun dalam aset tetap." Weston dan Brigham (2012:175) struktur aset adalah "Perimbangan atau perbandingan antara aset tetap dan total aset." Brigham dan Houston (2012:39) perusahaan yang asetnya sesuai untuk dijadikan jaminan kredit cenderung lebih banyak menggunakan banyak utang. Pengukuran struktur aset dilakukan dengan melakukan suatu perbandingan antara total hutang jangka panjang perusahaan dengan total aset yang dimiliki. Pengukuran struktur aset dapat dilakukan dengan melihat proporsi aset tetap perusahaan terhadap total aset perusahaan secara keseluruhan.

\subsection{Profitabilitas}

Setiap perusahaan yang bersifat profit oriented tentunya akan berusaha menggunakan setiap asset-asset yang dimiliki untuk menghasilkan laba yang optimal. Perusahaan juga akan melakukan pengukuran terhadap profitabilitas yang diperolehnya. Pengukuran terhadap profitabilitas akan memungkinkan bagi perusahaan, dalam hal ini manajemen untuk mengevaluasi tingkat earning dalam hubungannya dengan volume penjualan, jumlah aset dan investasi tertentu dari kelangsungan hidup suatu perusahaan, haruslah berada dalam keadaan yang menguntungkan atau profitable. Tanpa adanya keuntungan akan sulit bagi perusahaan untuk menarik modal dari luar.

Setiap perusahaan dalam menjalankan kegiatan bisnisnya akan berusaha untuk mengahasilkan laba atau profit yang optimal. Menurut Gitman (2012:629), mengemukakan bahwa: "Profitability is the relationship between revenue and cost generated by using the firm's assets both current and fixed in productive activities." Artinya hubungan antara pendapatan dan biaya-biaya yang dihasilkan dengan penggunaan asset perusahaan yang lancar dan tetap dalam aktivitas produktif. Sartono (2010:122) menyatakan : "Profitabilitas adalah Kempauan perusahaan memperoleh laba dalam hubungannya dengan penjualan, total aset maupun modal sendiri."

Return On Asset merupakan rasio antar laba bersih yang berbanding terbalik dengan keseluruhan aset untuk menghasilkan laba. Rasio ini menunjukkan berapa besar laba bersih yang diperoleh perusahaan diukur dari nilai asetnya. Analisis Return On assets atau sering diterjemahkan dalam bahasa Indonesia sebagai rentabilitas ekonomi mengukur perkembangan perusahaan menghasilkan laba pada masa lalu. Analisis ini kemudian diproyeksikan ke masa mendatang untuk melihat kemampuan perusahaan menghasilkan laba pada masa- 
masa mendatang.

Definisi Return On Asset (ROA) yaitu "Return On Asset (ROA) yaitu rasio antara Net Income After Tax terhadap aset secara keseluruhan menunjukan ukuran produktivitas aset dalam memberikan pengembalian pada penanaman modal".(Sawir, 2011). Henry Simamora mendefinisakan Return on Asset yaitu "Rasio imbalan aset (ROA) merupakan suatu ukuran keseluruhan profitabilitas perusahaan". (2012:529). M. Hanafi (2010:42) pengertian ROA adalah mengukur kemampuan perusahaan menghasilkan laba bersih berdasarkan tingkat aset yang tertentu. Brigham dan Houston (2012:148) mengatakan bahwa ROA adalah rasio laba bersih terhadap total aset mengukur pengembalian atas total aset. Eduardus Tandelilin (2010:372) menyatakan bahwa : "Return On Assets (ROA) menggambarkan sejauh mana kemampuan aset-aset yang dimiliki perusahaaan bisa menghasilkan laba."

Kasmir (2012:201) menyatakan bahwa : "ROA adalah rasio yang menunjukan hasil (return) atas jumlah aset yang digunakan dalam perusahaan. Selain itu, ROA memberikan ukuran yang lebih baik atas profitabilitas perusahaan karena menunjukan efektivitas manajemen dalam menggunakan aset untuk memperoleh pendapatan." I Made (2011:22), ROA adalah kemampuan perusahaan dengan menggunakan seluruh aset yang dimiliki untuk menghasilkan laba setelah pajak.

Berdasarkan definisi tersebut berarti Return On Assets (ROA) adalah suatu alat pengukuran yang digunakan untuk mengukur kemampuan manajemen dalam menghasilkan laba berdasarkan penggunaan aset perusahaan. Jika suatu perusahaan mempunyai Return On Assets (ROA) yang tinggi maka perusahaan tersebut berpeluang besar dalam meningkatkan pertumbuhan modal sendiri, tetapi jika total aset yang digunakan perusahaan tidak memberikan laba maka perusahaan akan mengalami kerugian dan akan menghambat pertumbuhan modal sendiri.

Profitabilitas adalah rasio yang mengukur kemampuan perusahaan menghasilkan laba. Return on Assets (ROA) termasuk salah satu rasio profitabilitas. Menurut kutipan dari Brigham dan Houston (2011:89), rasio profitabilitas (profitability ratio) menunjukkan pengaruh gabungan dari likuiditas, manajemen aset, dan utang terhadap hasil operasi.

\subsection{Pengembangan Hipotesis}

2.6.1. Pengaruh Pertumbuhan Penjualan Terhadap Struktur Modal

Perusahaan yang tumbuh dengan cepat, akan lebih banyak menggunakan modal eksternal. Perusahaan yang tumbuh dengan cepat akan banyak mengeluarkan biaya untuk mempertahankan dan meningkatkan pertumbuhan penjualannya. Perusahaan dengan tingkat pertumbuhan penjualan dan laba yang tinggi cenderung menggunakan hutang sebagai sumber dana eksternal yang lebih besar dibandingkan dengan perusahaan yang tingkat pertumbuhan penjualannya rendah. Berarti diprediksi pertumbuhan penjualan berpengaruh positif terhadap struktur modal.

\subsubsection{Pengaruh Ukuran Perusahaan Terhadap Struktur Modal}

Semakin besar ukuran sebuah perusahaan, maka kecenderungan untuk menggunakan dana eksternal semakin besar. Hal ini dikarenakan perusahaan besar 
memiliki kebutuhan dana melimpah. Salah satu solusi penyedia dana besar melalui hutang perusahaan. Berarti ukuran perusahaan diprediksi berpengaruh positif terhadap struktur modal

\subsubsection{Pengaruh Struktur Aset Terhadap Struktur Modal}

Total aset adalah hasil dari pertambahan aset tetap dengan aset tidak berwujud. Semakin besar perusahaan memiliki aset tetap dibanding aset tak berwujudnya, maka semakin besar juga nilai jaminan yang dimiliki oleh perusahaan untuk mendapatkan hutang yang bisa digunakan untuk operasional dan pengembangan perusahaan. Berarti diprediksi struktur aset berpengaruh positif terhadap penentuan struktur modal.

\subsubsection{Pengaruh Profitabilitas Terhadap Struktur Modal}

Perusahaan lebih menyukai menggunakan pendanaan internal yang terwujud dalam laba ditahan (menurut teori pecking order). Perusahaan yang memiliki tingkat profitabilitas tinggi akan menggunakan utang dalam jumlah kecil. Karena peningkatan profitabilitas perusahaan berbanding lurus dengan kenaikan jumlah laba ditahan. Semakin besar laba ditahan, maka akan berpengaruh negatif terhadap keputusan utang perusahaan. Berarti profitabilitas diprediksi berpengaruh negatif terhadap struktur modal.

Berdasarkan hubungan antara variabel diatas maka dapat dikembangkan suatu hipotesis yang merupakan jawaban teoritis terhadap rumusan masalah penelitian, belum jawaban yang empiris (Sugiyono, 2013: 93). Adapun hipotesis dalam penelitian ini adalah:

H1 : Terdapat pengaruh pertumbuhan penjualan terhadap struktur modal

$\mathrm{H} 2$ : Terdapat pengaruh ukuran perusahaan terhadap struktur modal

H3 : Terdapat pengaruh struktur aset terhadap struktur modal

H4 : Terdapat pengaruh profitabilitas terhadap struktur modal

H5 : Terdapat pengaruh pertumbuhan penjualan, ukuran perusahaan, struktur aset dan profitabilitas secara simultan terhadap struktur modal pada perusahaan manufaktur yang terdaftar di BEI terhadap struktur modal

\subsection{Kerangka Konseptual}

Di dalam suatu perusahaan, struktur modal harus diatur sedemikian rupa sehingga menjamin stabilitas finansial perusahaan, memang tidak ada ukuran yang pasti mengenai jumlah dan komposisi modal dari tiap-tiap perusahaan, tetapi pada dasarnya pengaturan terhadap struktur modal dalam perusahaan harus berorientasi pada tercapainya stabilitas finansial dan terjaminnya kelangsungan hidup perusahaan. Masalah struktur modal merupakan masalah yang penting bagi setiap perusahaan, karena baik buruknya struktur modal perusahaan akan mempunyai efek yang langsung terhadap posisi keuangan perusahaan. Struktur modal suatu perusahaan dipengaruhi oleh beberapa faktor. Suatu kerangka pemikiran penulis menggambarkan secara definitif konsep pengaruh ini diartikan sebagai suatu hubungan dari variabel independen dengan variabel dependen.

Memperjelas kerangka pemikiran di atas, maka kelima variabel dapat digambarkan dalam paradigma sederhana dengan empat variabel independen dan satu variabel dependen, sebagai berikut : 


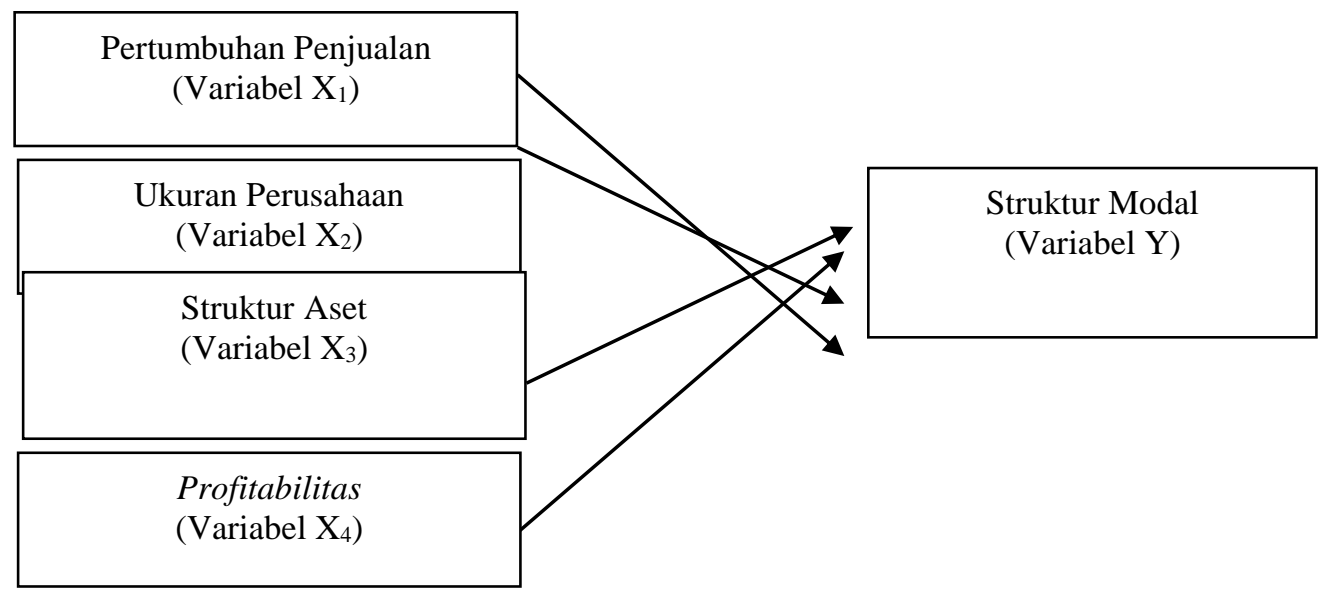

Gambar 1. Kerangka Pemikiran

\section{METODE PENELITIAN}

Strategi penelitian yang digunakan dalam penelitian ini adalah strategi penelitian asosiatif. Penelitian asosiatif digunakan karena sesuai untuk menjawab pertanyaan-pertanyaan yang bersifat pengaruh sebab akibat antara dua variabel atau lebih. Tujuan dari strategi asosiatif adalah agar dapat memberikan penjelasan tentang pengaruh pertumbuhan penjualan, ukuran perusahaan, struktur aset dan profitabilitas terhadap struktur modal pada perusahaan manufaktur yang terdaftar di BEI. Metode penelitian yang digunakan dalam penelitian ini adalah ex post facto, yaitu suatu penelitian yang dilakukan untuk meneliti peristiwa yang telah terjadi dalam tahun tertentu dan kemudian melihat kebelakang untuk mengetahui faktor-faktor yang menimbulkan kejadian tersebut. Dengan menggunakan metoda ini, dapat dibentuk suatu teori yang berfungsi untuk menjelaskan lebih dalam lagi mengenai pengaruh antara variabel bebas dan variabel terikat.

\subsection{Model Pengujian Hipotesis}

Pengujian hipotesis adalah penelitian yang menguji apakah ada atau tidak korelasi antar masing-masing variabel dependen dan variabel independen. Pengujian hipotesis yang digunakan dalam penelitian ini adalah analisis regresi linier berganda. Analisis ini dengan bantuan program Eviews 9.0 digunakan untuk menganalisis tingkat pengaruh satu variabel dependen dengan lebih dari satu variabel independen. Pengujian ini menggunakan persamaan sebagai berikut:

$$
\hat{Y}=a+b_{1} x_{1}+b_{2} x_{2}+b_{3} x_{3}+b_{4} x_{4}
$$

\subsection{Definisi dan Operasionalisasi Variabel}

Di dalam penelitian terdapat variabel-variabel yang satu sama lain saling mempengaruhi. Suharsimi Arikunto (2010:96) mengatakan bahwa "variabel adalah objek penelitian atau apa yang menjadi titik perhatian suatu penelitian" dalam penelitian ini terdapat 5 variabel yang akan diteliti, yaitu sebagai berikut : 


\subsubsection{Variabel Bebas $(X)$}

Adapun yang menjadi bebas dalam penelitian ini:

1) Pertumbuhan Penjualan

Pertumbuhan penjualan adalah perubahan penjualan perusahaan yang diukur berdasarkan perbandingan antara total penjualan periode sekarang minus periode sebelumnya terhadap total penjualan periode sebelumnya. Pertumbuhan penjualan dapat dirumuskan sebagai berikut (Horne, 2012:84) :

$$
\mathrm{g}=\frac{\mathrm{S}_{1}-\mathrm{S}_{0}}{\mathrm{~S}_{0}} \times 100 \%
$$

Keterangan :

$\mathrm{g}=$ Growth Sales Rate (tingkat pertumbuhan penjualan)

$\mathrm{S} 1$ = Total Current Sales (total penjualan selama periode berjalan)

S0 $=$ Total Sales For Last Period (total penjualan periode yang lalu)

2) Ukuran Perusahaan

Ukuran perusahaan diukur dari total aset perusahaan. Perusahaan dengan ukuran yang besar memiliki kecenderungan menggunakan hutang yang lebih banyak. Dimana ukuran perusahaan diproxy dengan nilai logaritma dari total aset. Logaritma dari total aset dijadikan indikator dari ukuran perusahaan karena jika semakin besar ukuran perusahaan maka aset tetap yang dibutuhkan juga akan semakin besar. Ukuran perusahaan jika dirumuskan menggunakan logaritma yaitu (Gitman, 2011:415):

$$
\text { Ukuran Perusahaan }=\log \text { Total asset }
$$

3) Struktur Aset

Struktur aset menggambarkan sebagian jumlah aset yang dapat dijadikan jaminan. Aset yang dimaksud adalah aset yang berhubungan dengan struktur modal perusahaan, terutama aset tetap.

Rumus penghitungan struktur aset ini adalah (Brigham dan Houston, 2012:39):

$$
\text { Tangibility of Asset Ratio }=\frac{\text { Fix Assets }}{\text { Total Assets }} \times 100 \%
$$

4) Profitabilitas

Profitabilitas perusahaan menunjukan kemampuan suatu perusahaan dalam menghasilkan laba selama periode tertentu pada tingkat penjualan, aset dan modal saham perusahaan. Berikut cara pengukuran profitabilitas (I Made, 2011:22) :

$$
\text { Return on assets }(R O A)=\frac{\text { Net Income After Tax }}{\text { Total Assets }}
$$




\subsubsection{Variabel Terikat}

Variabel terikat dalam penelitian ini adalah struktur modal yaitu debt to equity ratio. Rasio ini digunakan untuk mengetahui jumlah dana yang disediakan oleh kreditor dengan pemilik perusahaan sehingga rasio ini berfungsi untuk mengetahui setiap rupiah modal sendiri yang dijadikan jaminan utang. DER dirumuskan sebagai berikut (Kasmir, 2011:157-158) :

$$
\text { DER }=\frac{\text { Total Utang (Debt) }}{\text { Ekuitas (Equity) }}
$$

\subsection{Data, Populasi dan Sampel Penelitian}

\subsubsection{Data Penelitian}

Data yang diperoleh diambil melalui beberapa website dari bank yang bersangkutan yaitu perusahaan manufaktur yang terdaftar di BEI. Data yang digunakan dalam penelitian ini adalah data sekunder. Data sekunder adalah data yang diperoleh oleh suatu oganisasi atau lembaga atau perusahaan yang umumnya berupa bukti, catatan, atau laporan historis yang telah tersusun dalam arsip (data dokumenter) dalam bentuk yang sudah jadi berupa publikasi.

Sumber data, data yang digunakan dalam penelitian ini dapat digolongkan sebagai data eksternal. Data eksternal adalah data yang didapat di luar dari lembaga atau organisasi yang bersangkutan, yaitu perusahaan manufaktur yang terdaftar di BEI. Pengumpulan data dilakukan dengan observasi tidak langsung oleh peneliti terhadap objek penelitian yaitu perusahaan manufaktur yang terdaftar di BEI. Pengamatan yang dilakukan peneliti adalah pengamatan non partisipan, dimana penulis melakukan observasi sebagai pengumpul data tanpa melibatkan diri atau menjadi bagian dari lingkungan sosial yang diamati, dalam hal ini perusahaan tersebut.

\subsubsection{Populasi Penelitian}

Sugiyono (2012:144) menjelaskan "Populasi (population) adalah wilayah generalisasi yang terdiri atas objek atau subjek yang mempunyai kuantitas dan karakteristik tertentu yang ditetapkan oleh peneliti untuk dipelajari dan kemudian ditarik kesimpulannya". Populasi penelitian adalah seluurh perusahaan manufaktur yang terdaftar di BEI.

\subsubsection{Sampel Penelitian}

Sugiyono (2012:145), "Sampel adalah bagian dari jumlah dan karakteristik yang dimiliki oleh populasi tersebut". Metode pengambilan sampel yang digunakan adalah metode purposive sampling, yang merupakan metode pengambilan sampel berdasarkan ciri-ciri atau karakteristik tertentu yang dipandang mempunyai sangkut-paut yang erat dengan sifat populasi yang sudah diketahui. Oleh karena itu, sampel diambil dengan kriteria penilaian sebagai berikut : 
1) Sampel yang digunakan dalam penelitian ini termasuk dalam sector manufaktur berdasarkan pengklasifikasian Indonesian Capital Market Directory (ICMD).

2) Terdaftar sebagai perusahaan otomatif di BEI tahun 2012-2015

3) Laporan keuangan dinyatakan dalam Rupiah. Memiliki kelengkapan informasi laporan keuangan yang dibutuhkan dalam penelitian.

4) Sampel adalah emiten yang memiliki tahun buku per 31 Desember 2012-2015.

Sampel yang diambil oleh peneliti adalah 35 perusahaan manufaktur yang go publik di BEI dengan menggunakan data laporan keuangan berupa neraca dan laporan laba rugi pada periode tahun 2012-2015.

\subsection{Statistik Deskriptif}

Sebelum melakukan sebuah penelitian, peneliti terlebih dahulu melakukan pengumpulan dan pemilihan terhadap data perusahaan yang akan dijadikan sampel, sehingga sampel yang diambil harus benar-benar memenuhi kriteria yang sudah ditentukan dan bersifat representative terhadap hasil penelitian. Data yang akan diolah dalam penelitian ini menggunakan data sekunder yang di ambil dari Indonesia Capital Market Electronic Library (ICAMEL) yang terdapat di Bursa Efek Indonesia J1.Jend. Sudirman tower 2 1t. 2 Kav. 52-53 Jakarta.

Populasi dalam penelitian ini adalah 35 perusahaan manufaktur yang terdaftar di Bursa Efek Indonesia tahun 2012 sampai dengan 2015. Fokus penelitian ini adalah menganalisis Pertumbuhan penjualan $\left(\mathrm{X}_{1}\right)$, Ukuran perusahaan $\left(\mathrm{X}_{2}\right)$, Struktur aset $\left(\mathrm{X}_{3}\right)$ dan profitabilitas $\left(\mathrm{X}_{4}\right)$ Terhadap struktur modal (Y). Dalam penelitian ini adalah informasi mengenai laporan keuangan perusahaan. Sampel diambil berdasarkan kelengkapan dan kesesuaiannya terhadap kriteria yang ditetapkan dalam penelitian ini.

Analisis ini digunakan untuk memberikan gambaran atau deskripsi mengenai suatu data, dimana data yang diperoleh berasal dari hasil analisis deskriptif yang hasilnya memperlihatkan rata-rata (mean), nilai tertinggi (maximum), nilai terendah (minimum) dan standar deviasi dari setiap variabel yang diteliti baik itu variabel independen serta variabel dependen yaitu struktur modal. Statistik deskriptif dari masing-masing variabel yang diteliti adalah sebagai berikut: 
Tabel 2. Analisis Deskriptif Statistik Variabel Yang Diteliti

\begin{tabular}{cccccc} 
& $\mathrm{X} 1$ & $\mathrm{X} 2$ & $\mathrm{X} 3$ & $\mathrm{X} 4$ & $\mathrm{Y}$ \\
\hline Mean & 9.414396 & 14.94932 & 31.96517 & 11.59157 & 0.804429 \\
Median & 9.366550 & 14.77069 & 29.00674 & 9.320000 & 0.650000 \\
Maximum & 204.9042 & 19.31854 & 91.95705 & 71.51000 & 3.030000 \\
Minimum & -57.65855 & 11.64885 & 0.063212 & -6.050000 & 0.040000 \\
Std. Dev. & 26.89780 & 1.821404 & 18.22499 & 11.25787 & 0.619876 \\
Sum & 1318.015 & 2092.905 & 4475.124 & 1622.820 & 112.6200 \\
Observations & 140 & 140 & 140 & 140 & 140 \\
& & & & & Sumber www.idx.co.id Data diolah dengan E views
\end{tabular}

Berdasarkan hasil perhitungan dapat dilihat variabel pertumbuhan penjualan $\left(\mathrm{X}_{1}\right)$ menunjukkan nilai minimum sebesar $-57,65855$ dan nilai maksimum sebesar 204,9042. Nilai rata-rata pertumbuhan penjualan sebesar 9,414396. Sementara standar deviasi sebesar 26,89780 lebih besar dibandingkan nilai meannya. Berdasarkan hasil perhitungan dapat dilihat variabel ukuran perusahaan $\left(\mathrm{X}_{2}\right)$ dengan nilai minimum sebesar 11,64885 dan nilai maksimum sebesar 19,31854. Nilai rata-rata ukuran perusahaan sebesar 14,94932. Sementara standar deviasi sebesar 1,821404 lebih kecil jika dibandingkan nilai meannya.

Hasil statistik deskriptif Struktur aset $\left(\mathrm{X}_{3}\right)$ menunjukkan nilai minimum sebesar 0,063212 dan nilai maksimum sebesar 91,95705. Nilai rata-rata struktur aset sebesar 31,96517 dengan standar deviasi sebesar 18,22499 masih lebih kecil jika dibandingkan nilai meannya. Profitabilitas $\left(\mathrm{X}_{4}\right)$ pada tabel atas, hasil statistik deskriptif menunjukkan nilai minimum sebesar $-6,05$ dan nilai maksimum sebesar 71,51. Nilai rata-rata Profitabilitas sebesar 11,59157. Sementara standar deviasi sebesar 11,25787, masih lebih kecil jika dibandingkan nilai meannya. Berdasarkan hasil perhitungan dapat dilihat variabel struktur modal (Y) menunjukkan nilai minimum sebesar 0,04 dan nilai maksimum sebesar 3,03. Nilai rata-rata Struktur modal sebesar 0,804429. Sementara standar deviasi sebesar 0,619876 masih lebih kecil jika dibandingkan nilai meannya.

\section{HASIL PENELITIAN DAN PEMBAHASAN}

4.1. Hasil Pengujian Hipotesis

4.1.1. Analisis Regresi Data Panel

Analisis dengan data panel digunakan untuk menghitung berapa besar pengaruh Pengaruh Pertumbuhan penjualan, Ukuran perusahaan, Struktur aset dan profitabilitas Terhadap struktur modal dari perhitungan atau analisis data panel dengan menggunakan Eviews 9. Mengetahui metode yang paling efisien dari tiga model persamaan yaitu Panel Least Square (PLS), Fixed Effect Model (FEM) dan Random Effect Model (REM) masing-masing perlu diuji dengan menggunakan metode regresi data panel, dengan hasil sebagai berikut:

\section{1) Common Effect Model (CEM)}

Metode ini menggabungkan data time-series dan cross-section kemudian diregresikan dalam metode OLS, hasil perhitungan dengan menggunakan program EViews dapat dilihat pada tabel berikut: 
Tabel 3. Hasil Regresi Model Common Effect

\begin{tabular}{|c|c|c|c|c|}
\hline \multicolumn{5}{|c|}{$\begin{array}{l}\text { Dependent Variable: Y? } \\
\text { Method: Panel Least Squares } \\
\text { Date: } 08 / 09 / 17 \text { Time: } 11: 59 \\
\text { Sample: } 20122015 \\
\text { Included observations: } 4 \\
\text { Cross-sections included: } 35 \\
\text { Total pool (balanced) observations: } 140\end{array}$} \\
\hline Variable & Coefficient & Std. Error & t-Statistic & Prob. \\
\hline $\mathrm{C}$ & -1.110240 & 0.398519 & -2.785917 & 0.0061 \\
\hline $\mathrm{X} 1 ?$ & 0.000491 & 0.001794 & 0.273695 & 0.7847 \\
\hline$X 2 ?$ & 0.103449 & 0.026244 & 3.941869 & 0.0001 \\
\hline X3? & 0.008250 & 0.002657 & 3.105091 & 0.0023 \\
\hline $\mathrm{X} 4 ?$ & 0.008612 & 0.004315 & 1.996147 & 0.0479 \\
\hline R-squared & 0.203384 & \multicolumn{2}{|c|}{ Mean dependent var } & 0.804429 \\
\hline Adjusted R-squared & 0.179781 & \multicolumn{2}{|c|}{ S.D. dependent var } & 0.619876 \\
\hline S.E. of regression & 0.561397 & \multicolumn{2}{|c|}{ Akaike info criterion } & 1.718283 \\
\hline Sum squared resid & 42.54744 & \multicolumn{2}{|c|}{ Schwarz criterion } & 1.823342 \\
\hline Log likelihood & -115.2798 & \multirow{2}{*}{\multicolumn{2}{|c|}{ Hannan-Quinn criter. }} & 1.760976 \\
\hline F-statistic & 8.616730 & & & 0.432455 \\
\hline Prob(F-statistic) & 0.000003 & \multicolumn{2}{|c|}{ Durbin-Watson stat } & \\
\hline
\end{tabular}

Sumber : Data diolah dengan E views

Berdasarkan hasil regresi menggunakan model Common Effect (PLS) di atas dapat disimpulkan bahwa koefisien regresi konstanta sebesar 1.110240, nilai t-Statistik sebesar -2.785917 dengan probabilitas sebesar $0.0061<0.05$, sedangkan koefisien regresi Pertumbuhan penjualan $\left(\mathrm{X}_{1}\right)$ sebesar 0.000491 nilai t-Statistik sebesar 0.273695 dengan probabilitas sebesar $0.7847>0.05$ artinya variabel Pertumbuhan penjualan berpengaruh terhadap struktur modal tetapi tidak signifikan pada tingkat $\alpha=5 \%$, sedangkan untuk variabel Ukuran perusahaan $\left(\mathrm{X}_{2}\right)$ mempunyai koefisien regresi sebesar 0.103449 nilai t-Statistik sebesar 3.941869 dengan probabilitas sebesar 0.0001 $<0.05$ artinya variabel Ukuran perusahaan berpengaruh terhadap struktur modal dan signifikan pada tingkat $\alpha=5 \%$, variabel struktur aset $\left(\mathrm{X}_{3}\right)$ mempunyai koefisien regresi sebesar 0.008250 nilai t-Statistik sebesar 3.105091 dengan probabilitas sebesar $0.0023<0.05$ artinya variabel struktur aset berpengaruh terhadap struktur modal dan signifikan pada tingkat $\alpha=5 \%$, dan variabel Profitabilitas $\left(\mathrm{X}_{4}\right)$ mempunyai koefisien regresi sebesar 0.008612 nilai t-Statistik sebesar 1.996147 dengan probabilitas sebesar $0.0479<0.05$ artinya variabel Profitabilitas berpengaruh terhadap struktur modal tetapi signifikan pada tingkat $\alpha=5 \%$.

2) Fixed Effect Model (FEM)

Metode ini mengasumsikan bahwa koefisien regresi (slope) tetap antar perusahaan dan antar waktu. Hasil perhitungan dengan menggunakan program Eviews, maka output dari regresi menggunakan model Fixed Effect (FEM) adalah sebagai berikut: 
Tabel 4. Hasil Regresi Model Fixed Effect (FEM)

Dependent Variable: Y?

Method: Panel Least Squares

Date: 08/09/17 Time: $12: 00$

Sample: 20122015

Included observations: 4

Cross-sections included: 35

Total pool (balanced) observations: 140

\begin{tabular}{|c|c|c|c|c|}
\hline Variable & Coefficient & Std. Error & t-Statistic & Prob. \\
\hline C & -0.098079 & 2.017522 & -0.048614 & 0.9613 \\
\hline $\mathrm{X} 1 ?$ & 0.001128 & 0.000861 & 1.310742 & 0.1929 \\
\hline $\mathrm{X} 2 ?$ & 0.049526 & 0.132473 & 0.373858 & 0.7093 \\
\hline X3? & 0.009070 & 0.002456 & 3.692331 & 0.0004 \\
\hline \multirow[t]{2}{*}{$X 4 ?$} & -0.011942 & 0.004600 & -2.596024 & 0.0108 \\
\hline & \multicolumn{4}{|c|}{ Effects Specification } \\
\hline \multicolumn{5}{|c|}{ Cross-section fixed (dummy variables) } \\
\hline R-squared & 0.877322 & \multicolumn{2}{|c|}{ Mean dependent var } & 0.804429 \\
\hline Adjusted R-squared & 0.831166 & \multicolumn{2}{|c|}{ S.D. dependent var } & 0.619876 \\
\hline S.E. of regression & 0.254703 & \multicolumn{2}{|c|}{ Akaike info criterion } & 0.333186 \\
\hline Sum squared resid & 6.552250 & \multicolumn{2}{|c|}{ Schwarz criterion } & 1.152644 \\
\hline Log likelihood & 15.67697 & \multicolumn{2}{|c|}{ Hannan-Quinn criter. } & 0.666189 \\
\hline F-statistic & 19.00777 & \multicolumn{2}{|c|}{ Durbin-Watson stat } & 2.252025 \\
\hline Prob(F-statistic) & 0.000000 & & & \\
\hline
\end{tabular}

Sumber : Data diolah dengan E views

Berdasarkan hasil regresi menggunakan Fixed Effect Model (FEM) di atas dapat disimpulkan bahwa koefisien regresi konstanta sebesar -0.098079, nilai t-Statistik sebesar -0.048614 dengan probabilitas sebesar $0.0913>0.05$, sedangkan koefisien regresi Pertumbuhan penjualan $\left(\mathrm{X}_{1}\right)$ sebesar 0.001128 nilai t-Statistik sebesar 1.310742 dengan probabilitas sebesar $0.1929>0.05$ artinya variabel Pertumbuhan penjualan berpengaruh terhadap struktur modal dan tidak signifikan pada tingkat $\alpha=5 \%$, sedangkan untuk variabel Ukuran perusahaan $\left(\mathrm{X}_{2}\right)$ mempunyai koefisien regresi sebesar 0.049526 nilai tStatistik sebesar 0.373858 dengan probabilitas sebesar $0.7093>0.05$ artinya variabel Ukuran perusahaan berpengaruh terhadap struktur modal dan tidak signifikan pada tingkat $\alpha=5 \%$, variabel struktur aset $\left(\mathrm{X}_{3}\right)$ mempunyai koefisien regresi sebesar 0.009070 nilai t-Statistik sebesar 3.692331 dengan probabilitas sebesar $0.0004<0.05$ artinya variabel struktur aset berpengaruh terhadap struktur modal dan signifikan pada tingkat $\alpha=5 \%$, dan variabel Profitabilitas $\left(\mathrm{X}_{4}\right)$ mempunyai koefisien regresi sebesar -0.011942 nilai $t-$ Statistik sebesar -2.596024 dengan probabilitas sebesar $0.0108<0.05$ artinya variabel Profitabilitas berpengaruh terhadap struktur modal tetapi signifikan pada tingkat $\alpha=5 \%$.

\section{3) Random Effect Model (REM)}

Model Random Effect adalah metode yang akan mengestimasi data panel di mana variabel gangguan mungkin saling berhubungan antar waktu 
dan antar individu. Hasil perhitungannya adalah sebagai berikut:

Tabel 5. Hasil Regresi Model Random Effect Model (REM)

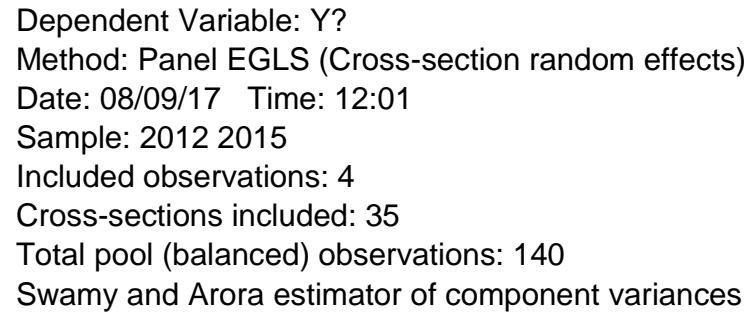

\begin{tabular}{lllll}
\hline \hline Variable & Coefficient & Std. Error & t-Statistic & Prob. \\
\hline \hline C & -0.978403 & 0.709797 & -1.378425 & 0.1704 \\
X1? & 0.001068 & 0.000858 & 1.245789 & 0.2150 \\
X2? & 0.104564 & 0.046329 & 2.257004 & 0.0256 \\
X3? & 0.009012 & 0.002224 & 4.052600 & 0.0001 \\
X4? & -0.006769 & 0.003894 & -1.738255 & 0.0844 \\
\hline \hline & Effects Specification & & \\
& & & S.D. & Rho \\
\hline \hline & & & 0.516636 & 0.8045 \\
Cross-section random & & & 0.254703 & 0.1955 \\
\hline \hline
\end{tabular}

\begin{tabular}{llll}
\hline \hline & \multicolumn{4}{l}{ Weighted Statistics } \\
\hline \hline R-squared & 0.151141 & Mean dependent var & 0.192530 \\
Adjusted R-squared & 0.125990 & S.D. dependent var & 0.274989 \\
S.E. of regression & 0.257083 & Sum squared resid & 8.922393 \\
F-statistic & 6.009253 & Durbin-Watson stat & 1.672040 \\
Prob(F-statistic) & 0.000176 & & \\
\hline \hline & Unweighted Statistics & \\
\hline \hline R-squared & 0.127982 & Mean dependent var & \multirow{2}{*}{0.804429} \\
Sum squared resid & 46.57470 & Durbin-Watson stat & 1.320315 \\
\hline \hline
\end{tabular}

Sumber : Data diolah dengan E views

Berdasarkan hasil regresi menggunakan Random Effect Model (REM) di atas dapat disimpulkan bahwa koefisien regresi konstanta sebesar -0.978403 nilai t-Statistik sebesar -1.378425 dengan probabilitas sebesar $0.1704>0.05$, sedangkan koefisien regresi Pertumbuhan penjualan $\left(\mathrm{X}_{1}\right)$ sebesar 0.001068 nilai t-Statistik sebesar 1.245789 dengan probabilitas sebesar $0.2150>0.05$ artinya variabel Pertumbuhan penjualan berpengaruh terhadap struktur modal tetapi tidak signifikan pada tingkat $\alpha=5 \%$, sedangkan untuk variabel Ukuran perusahaan $\left(\mathrm{X}_{2}\right)$ mempunyai koefisien regresi sebesar 0.104564 nilai tStatistik sebesar 2.257004 dengan probabilitas sebesar $0.0256<0.05$ artinya variabel Ukuran perusahaan berpengaruh terhadap struktur modal dan signifikan pada tingkat $\alpha=5 \%$, variabel struktur aset $\left(X_{3}\right)$ mempunyai 
koefisien regresi sebesar 0.009012 nilai t-Statistik sebesar 4.052600 dengan probabilitas sebesar $0.0001<0.05$ artinya variabel struktur aset berpengaruh terhadap struktur modal dan signifikan pada tingkat $\alpha=5 \%$, dan variabel Profitabilitas $\left(\mathrm{X}_{4}\right)$ mempunyai koefisien regresi sebesar -0.006769 nilai tStatistik sebesar -1.738255 dengan probabilitas sebesar $0.0844>0.05$ artinya variabel Profitabilitas berpengaruh terhadap struktur modal tetapi tidak signifikan pada tingkat $\alpha=5 \%$.

\subsubsection{Uji Metode Estimasi Model}

Menguji persamaan regresi yang diestimasi dapat digunakan pengujian sebagai berikut:

1) Uji Chow

Chow test (Uji Chow) yakni pengujian untuk menentukan model Fixed Effect atau Common Effect yang paling tepat digunakan dalam mengestimasi data panel. Hipotesis dalam Uji Chow adalah :

$\mathrm{H}_{0}$ : Common Effect Model

$\mathrm{H}_{1}$ : Fixed Effect Model

Tabel 6. Hasil Uji Chow

Redundant Fixed Effects Tests

Pool: POLL

Test cross-section fixed effects

\begin{tabular}{llll}
\hline \hline Effects Test & Statistic & d.f. & Prob. \\
\hline \hline Cross-section F & 16.319110 & $(34,101)$ & 0.0000 \\
Cross-section Chi-square & 261.913570 & 34 & 0.0000 \\
\hline \hline
\end{tabular}

Cross-section fixed effects test equation:

Dependent Variable: Y?

Method: Panel Least Squares

Date: 08/09/17 Time: 12:01

Sample: 20122015

Included observations: 4

Cross-sections included: 35

Total pool (balanced) observations: 140

\begin{tabular}{lllll}
\hline \hline Variable & Coefficient & Std. Error & t-Statistic & Prob. \\
\hline \hline C & -1.110240 & 0.398519 & -2.785917 & 0.0061 \\
X1? & 0.000491 & 0.001794 & 0.273695 & 0.7847 \\
X2? & 0.103449 & 0.026244 & 3.941869 & 0.0001 \\
X3? & 0.008250 & 0.002657 & 3.105091 & 0.0023 \\
X4? & 0.008612 & 0.004315 & 1.996147 & 0.0479 \\
\hline \hline R-squared & 0.203384 & Mean dependent var & 0.804429 \\
Adjusted R-squared & 0.179781 & S.D. dependent var & 0.619876 \\
S.E. of regression & 0.561397 & Akaike info criterion & 1.718283 \\
Sum squared resid & 42.54744 & Schwarz criterion & 1.823342 \\
Log likelihood & -115.2798 & Hannan-Quinn criter. & 1.760976
\end{tabular}




$\begin{array}{llll}\text { F-statistic } & 8.616730 & \text { Durbin-Watson stat } & 0.432455 \\ \text { Prob(F-statistic) } & 0.000003 & \end{array}$

Sumber : Data diolah dengan E views

Hasil dari Uji Chow dapat disimpulkan bahwa $\mathrm{H}_{0}$ ditolak karena hasil Prob Cross-section Chi Square lebih kecil dari alpha $(0,000<0,05)$, sehingga model yang dipakai dalam penelitian ini adalah Fixed Effect Model.

2) Uji Hausman

Setelah melakukan Uji Chow dan didapatkan model yang tepat adalah Fixed Effect, maka selanjutnya kita akan menguji model manakah antara Fixed Effect atau Random Effect yang paling tepat, pengujian ini disebut sebagai Uji Hausman.

Hipotesis dalam Uji Hausman :

$\mathrm{H}_{0}$ : Random Effect Model

$\mathrm{H}_{1}$ : Fixed Effect Model

Tabel 7. Hasil Uji Hausman

Correlated Random Effects - Hausman Test

Pool: POLL

Test cross-section random effects

\begin{tabular}{|c|c|c|c|c|}
\hline Test Summary & & $\begin{array}{l}\text { Chi-Sq. } \\
\text { Statistic }\end{array}$ & Chi-Sq. d.f. & Prob. \\
\hline Cross-section random & & 6.534678 & 4 & 0.1626 \\
\hline \multicolumn{5}{|c|}{ Cross-section random effects test comparisons: } \\
\hline Variable & Fixed & Random & Var(Diff.) & Prob. \\
\hline $\mathrm{X} 1 ?$ & 0.001128 & 0.001068 & 0.000000 & 0.4098 \\
\hline $\mathrm{X} 2 ?$ & 0.049526 & 0.104564 & 0.015403 & 0.6574 \\
\hline X3? & 0.009070 & 0.009012 & 0.000001 & 0.9556 \\
\hline X4? & -0.011942 & -0.006769 & 0.000006 & 0.0346 \\
\hline
\end{tabular}

Cross-section random effects test equation:

Dependent Variable: Y?

Method: Panel Least Squares

Date: 08/09/17 Time: 12:02

Sample: 20122015

Included observations: 4

Cross-sections included: 35

Total pool (balanced) observations: 140

\begin{tabular}{lllll}
\hline \hline Variable & Coefficient & Std. Error & t-Statistic & Prob. \\
\hline \hline C & -0.098079 & 2.017522 & -0.048614 & 0.9613 \\
X1? & 0.001128 & 0.000861 & 1.310742 & 0.1929 \\
X2? & 0.049526 & 0.132473 & 0.373858 & 0.7093 \\
X3? & 0.009070 & 0.002456 & 3.692331 & 0.0004 \\
X4? & -0.011942 & 0.004600 & -2.596024 & 0.0108 \\
\hline \hline
\end{tabular}




\begin{tabular}{llll}
\hline \hline Cross-section fixed (dummy variables) & & \\
\hline \hline R-squared & 0.877322 & Mean dependent var & 0.804429 \\
Adjusted R-squared & 0.831166 & S.D. dependent var & 0.619876 \\
S.E. of regression & 0.254703 & Akaike info criterion & 0.333186 \\
Sum squared resid & 6.552250 & Schwarz criterion & 1.152644 \\
Log likelihood & 15.67697 & Hannan-Quinn criter. & 0.666189 \\
F-statistic & 19.00777 & Durbin-Watson stat & 2.252025 \\
Prob(F-statistic) & 0.000000 & & \\
\hline \hline
\end{tabular}

Sumber : Data diolah dengan E views

Berdasarkan Uji Hausman dapat disimpulkan bahwa $\mathrm{H}_{0}$ di terima karena hasil Prob Cross-section random lebih besar dari alpha $(0.1626>0,05)$, sehingga model yang dipakai dalam penelitian ini adalah Random Effect Model.

3) Uji Lagrange Multiplier

Lagrange Multiplier (LM) adalah uji untuk mengetahui apakah model Random Effect atau model Common Effect (OLS) yang paling tepat digunakan. Uji signifikasi Random Effect ini dikembangkan oleh Breusch Pagan. Metode Breusch Pagan untuk uji signifikasi Random Effect didasarkan pada nilai residual dari metode OLS.

Hipotesis yang digunakan adalah :

$\mathrm{H}_{0}$ : Common Effect Model

$\mathrm{H}_{1}$ : Random Effect Model

Tabel 8. Uji Lagrange Multiplier

Lagrange Multiplier Tests for Random Effects

Null hypotheses: No effects

Alternative hypotheses: Two-sided (Breusch-Pagan) and one-sided

(all others) alternatives

\begin{tabular}{|c|c|c|c|}
\hline & $\begin{array}{l}\text { Test Hypothesis } \\
\text { Cross-section }\end{array}$ & Time & Both \\
\hline Breusch-Pagan & $\begin{array}{l}74.19111 \\
(0.0000)\end{array}$ & $\begin{array}{l}2.642490 \\
(0.1040)\end{array}$ & $\begin{array}{l}76.83360 \\
(0.0000)\end{array}$ \\
\hline Honda & $\begin{array}{l}8.613426 \\
(0.0000)\end{array}$ & $\begin{array}{l}-1.625574 \\
--\end{array}$ & $\begin{array}{l}4.941158 \\
(0.0000)\end{array}$ \\
\hline King-Wu & $\begin{array}{l}8.613426 \\
(0.0000)\end{array}$ & $\begin{array}{l}-1.625574 \\
--\end{array}$ & $\begin{array}{l}4.318390 \\
(0.0000)\end{array}$ \\
\hline Standardized Honda & $\begin{array}{l}9.857979 \\
(0.0000)\end{array}$ & $\begin{array}{l}-1.469554 \\
--\end{array}$ & $\begin{array}{l}2.952486 \\
(0.0016)\end{array}$ \\
\hline Standardized King-Wu & $\begin{array}{l}9.857979 \\
(0.0000)\end{array}$ & $\begin{array}{l}-1.469554 \\
--\end{array}$ & $\begin{array}{l}2.242719 \\
(0.0125)\end{array}$ \\
\hline Gourierioux, et al.* & -- & -- & $\begin{array}{l}74.19111 \\
(<0.01)\end{array}$ \\
\hline
\end{tabular}

*Mixed chi-square asymptotic critical values:

$1 \% \quad 7.289$

$5 \% \quad 4.321$ 
$10 \% \quad 2.952$

Sumber : Data diolah dengan E views

Berdasarkan tabel 8 nilai Prob. Breusch-Pagan (BP) sebesar 0,0000, menunjukkan bahwa $\mathrm{H}_{0}$ diterima $\mathrm{H}_{1}$ ditolak. Artinya, bahwa model random effect dipilih dalam uji Lagrange Multiplier. Berdasarkan uji model Chow-test menunjukkan bahwa Fixed Effect Model yang dipilih. Di sisi lain, hasil dari uji model Hausman menunjukkan bahwa Random Effect Model yang dipilih dan hasil dari uji model Lagrange Multiplier menunjukkan bahwa Random Effect dipilih. Dari hasil tersebut terbukti model panel yang dipilih adalah model Random Effect Model.

\subsubsection{Uji Asumsi Klasik}

1) Uji Normalitas Data

Uji ini dilakukan untuk mengetahui apakah data yang digunakan terdapat atau mempunyai distribusi normal atau dalam kata lain dapat mewakili populasi yang sebarannya normal. Pengujian ini menggunakan metode grafik histogram dan uji statistik Jarque-Bera (JB test) sebagai berikut:
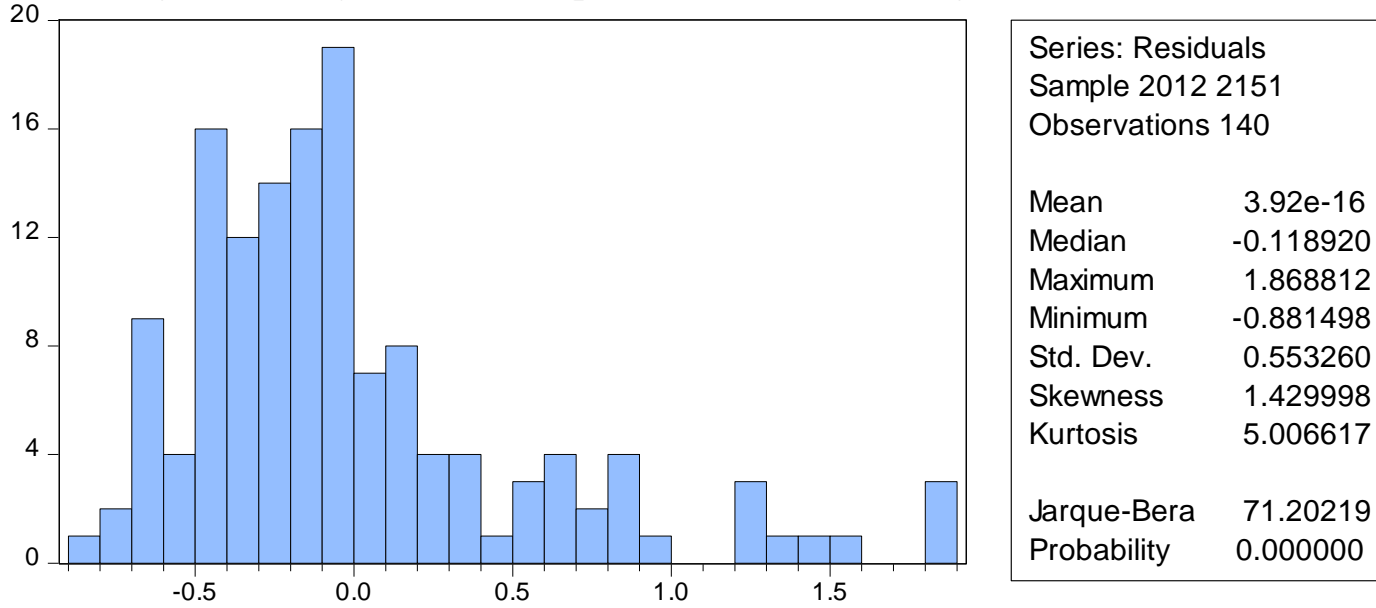

Sumber : Data diolah dengan E views

Gambar 2. Grafik Hasil Uji Normalitas Data

Dari histogram di atas nilai JB sebesar 71.20219 sementara nilai Chi Square dengan melihat jumlah variabel independen yang kita pakai dalam hal ini 4 variabel independen dan nilai signifikan yang kita pakai dalam hal ini 0,05 atau $5 \%$.

2) Uji Multikolinearitas

Uji multikolinearitas ini bertujuan untuk menguji dan mengetahui apakah dalam model regresi yang diolah ditemukan adanya korelasi atau hubungan antar variabel independen. Menguji masalah multikolinearitas dapat dilihat dari nilai correlation matrix dan dapat dilihat pada tabel di bawah ini: 
Tabel 9. Hasil Uji Multikolinearitas

\begin{tabular}{lcccc} 
& \multicolumn{1}{c}{$\mathrm{X} 1$} & $\mathrm{X} 2$ & $\mathrm{X} 3$ & $\mathrm{X} 4$ \\
\hline $\mathrm{X} 1$ & 1 & -0.0008434182878059706 & 0.088786739236444457 & 0.1459056405750187 \\
$\mathrm{X} 2$ & -0.0008434182878059706 & 1 & 0.08756748553591341 & 0.01474100840514173 \\
$\mathrm{X} 3$ & 0.08878673923644457 & 0.08756748553591341 & 1 & 0.1452599095127542 \\
$\mathrm{X} 4$ & 0.1459056405750187 & 0.01474100840514173 & 0.1452599095127542 & 1 \\
& & & Sumber : Data diolah dengan E views
\end{tabular}

Tabel di atas dapat dilihat nilai koefisien korelasi antar variabel independen kurang dari 0,80 dengan demikian data dalam penelitian ini dapat diidentifikasi tidak terjadi masalah multikolinearitas antar variabel independennya dan dapat dikatakan bahwa model ini dapat digunakan untuk mengestimasi pengaruh Pertumbuhan penjualan, Ukuran perusahaan, Struktur aset dan profitabilitas Terhadap struktur modal Pada Perusahaan manufaktur Yang Terdaftar di BEI Tahun 2012-2015.

Tabel 10. Hasil Uji Variance Inflation Factor (VIF)

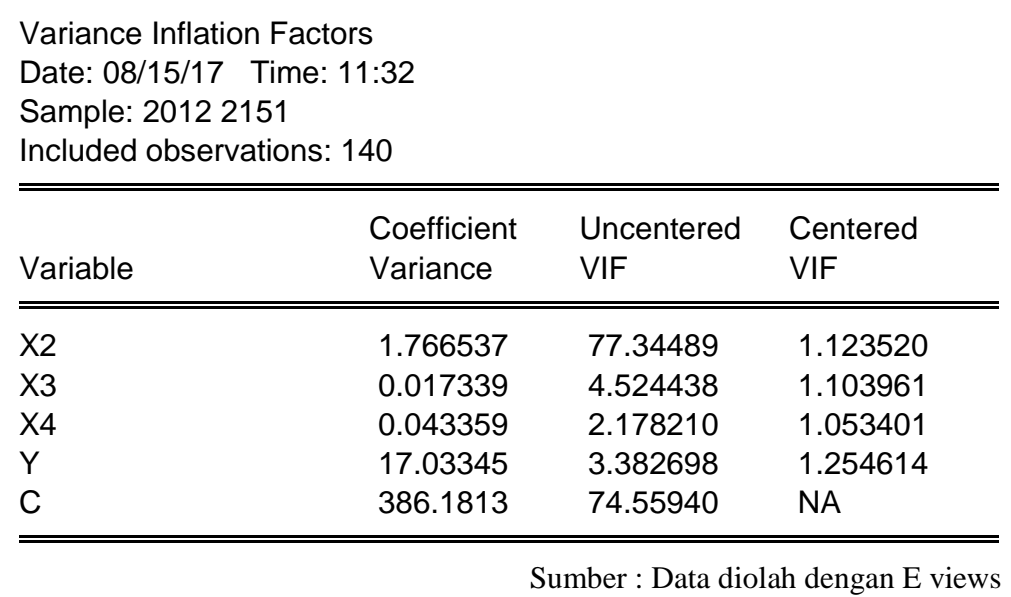

Berdasarkan hasil output pengujian multikolinearitas yang tampak pada tabel di atas, dapat dilihat pada tabel Coefficients (nilai Tolerance dan VIF) bahwa dari tiga variabel bebas dapat diketahui nilai VIF kurang dari 10 dan nilai Tolerance lebih besar dari 0,1, maka dapat disimpulkan bahwa model regresi tidak terjadi masalah multikolinearitas.

3) Uji Heteroskedastisitas

Uji heteroskedastisitas bertujuan untuk menguji apakah dalam model regresi yang terbentuk terjadi ketidaksamaan varian dari residual model regresi. Data yang baik adalah data yang homoskedastisitas. Uji Glejser dapat diidentifikasi masalah heterokedastisitas dari hasil perhitungan yang mengidentifikasikan tidak ada heterokedastisitas karena nilai koefisien regresi variabel independen tidak signifikan terhadap Dependent Variable RESABS Hipotesis yang digunakan adalah :

$\mathrm{H}_{0}$ : Tidak ada masalah heteroskedastisitas

$\mathrm{H}_{1}$ : Ada masalah heteroskedastisitas 


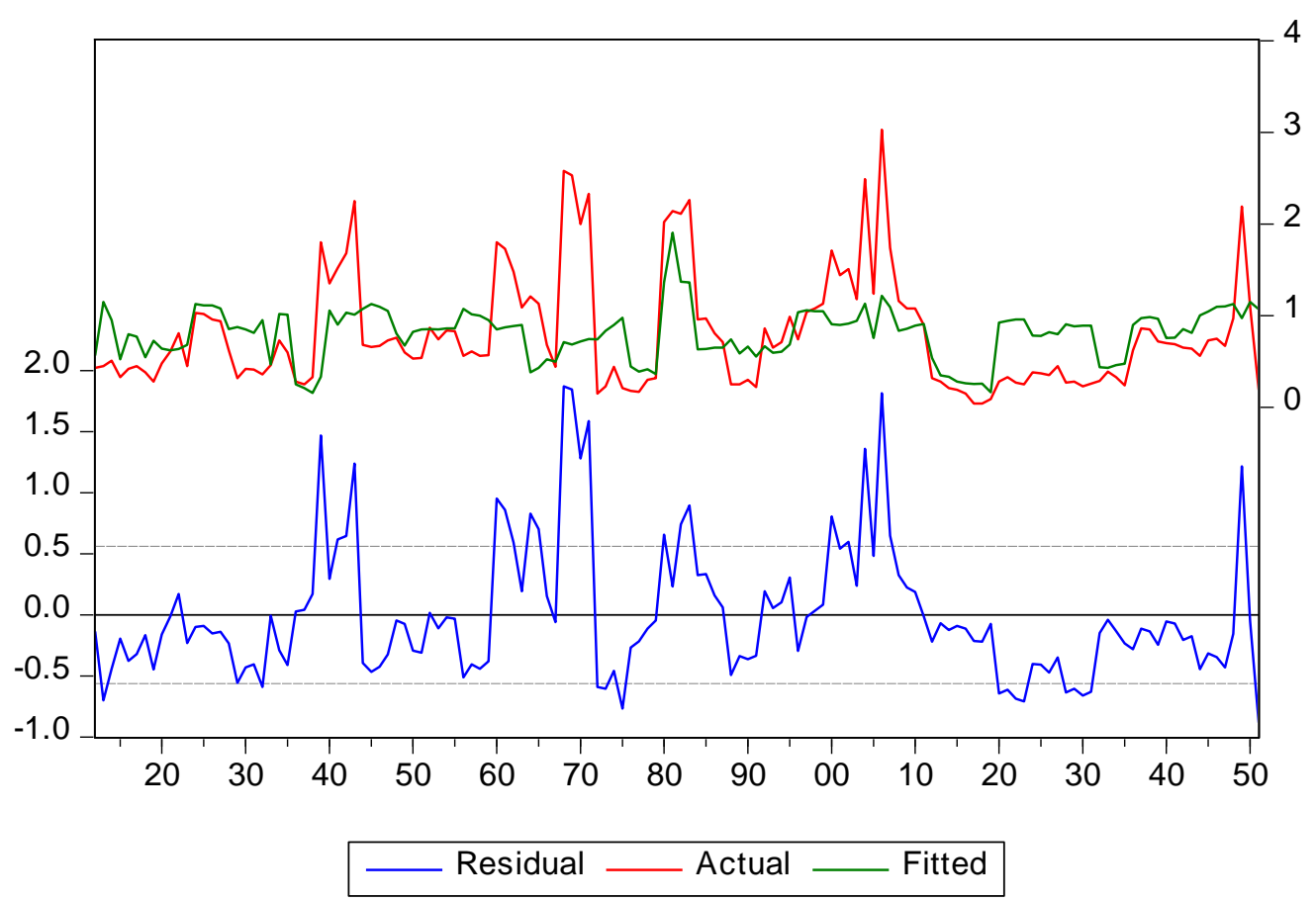

Sumber : Data diolah dengan E views

Grafik 3. Hasil Uji Heteroskedastisitas

Hasil dari Uji Glejser dapat disimpulkan bahwa $\mathrm{H}_{0}$ diterima karena hasil probabilitas setiap variabel independen lebih besar dari alpha (0.05), atau dengan kata lain nilai koefisien regresi variabel independen, sehingga data dalam model regresi ini dapat dikatakan tidak terdapat masalah heteroskedastisitas.

4) Uji Autokorelasi

Uji autokorelasi dalam penelitian ini dilakukan dengan metode DurbinWatson (DW). Model terbaik dalam regresi yang terbentuk yaitu Random Effect dapat dilihat bahwa nilai DW dari persamaan regresi yang terbentuk adalah sebesar 1.672040 jadi dapat disimpulkan maka nilai DW dari model regresi yang terbentuk pada penelitian ini tidak ada autokorelasi.

\subsubsection{Uji Persamaan Regresi Linier Berganda}

Analisis regresi linear berganda dimaksudkan untuk menguji sejauh mana dan arah pengaruh variabel-variabel independen terhadap variabel dependen. Variabel independen dalam penelitian ini adalah Pertumbuhan penjualan $\left(\mathrm{X}_{1}\right)$, Ukuran perusahaan $\left(\mathrm{X}_{2}\right)$, Struktur aset $\left(\mathrm{X}_{3}\right)$ dan profitabilitas $\left(\mathrm{X}_{4}\right)$. Sedangkan variabel dependennya adalah Struktur modal (Y) dengan menggunakan model Random Effect. 
Tabel 11. Uji Persamaan Regresi Linier Berganda

Dependent Variable: $Y$ ?

Method: Panel EGLS (Cross-section random effects)

Date: 08/09/17 Time: 12:01

Sample: 20122015

Included observations: 4

Cross-sections included: 35

Total pool (balanced) observations: 140

Swamy and Arora estimator of component variances

\begin{tabular}{lllll}
\hline \hline Variable & Coefficient & Std. Error & t-Statistic & Prob. \\
\hline \hline C & -0.978403 & 0.709797 & -1.378425 & 0.1704 \\
X1? & 0.001068 & 0.000858 & 1.245789 & 0.2150 \\
X2? & 0.104564 & 0.046329 & 2.257004 & 0.0256 \\
X3? & 0.009012 & 0.002224 & 4.052600 & 0.0001 \\
X4? & -0.006769 & 0.003894 & -1.738255 & 0.0844 \\
\hline \hline
\end{tabular}

\begin{tabular}{llll}
\hline \hline & Effects Specification & S.D. & Rho \\
\hline \hline $\begin{array}{llll}\text { Cross-section random } \\
\text { Idiosyncratic random }\end{array}$ & & 0.516636 & 0.8045 \\
& & 0.254703 & 0.1955 \\
\hline \hline & Weighted Statistics & \\
\hline \hline R-squared & 0.151141 & Mean dependent var & 0.192530 \\
Adjusted R-squared & 0.125990 & S.D. dependent var & 0.274989 \\
S.E. of regression & 0.257083 & Sum squared resid & 8.922393 \\
F-statistic & 6.009253 & Durbin-Watson stat & 1.672040 \\
Prob(F-statistic) & 0.000176 & & \\
\hline \hline & Unweighted Statistics & \\
\hline \hline R-squared & 0.127982 & Mean dependent var & 0.804429 \\
Sum squared resid & 46.57470 & Durbin-Watson stat & 1.320315 \\
\hline \hline
\end{tabular}

Sumber : Data diolah dengan E views

Berdasarkan hasil di atas, di dapat persamaan regresi linier berganda sebagai berikut :

$$
S M=-0.978403+0.001068 X_{1}+0.104564 X_{2}+0.009012 X_{3}-0.006769 X_{4}+e
$$

Keterangan :

$\mathbf{Y}_{\overline{\mathrm{E}}}=$ Struktur modal (SM)

$\mathbf{X}_{1}=$ Pertumbuhan penjualan

$\mathbf{X}_{\mathbf{2}}=$ Ukuran perusahaan

$\mathbf{X}_{3}=$ Struktur aset

$\mathbf{X}_{4}=$ Profitabilitas

$\alpha=$ Konstanta

e $=$ Error, tingkat kesalahan

Berdasarkan persamaan regresi linier berganda tersebut dapat 
dianalisis pengaruh masing-masing variabel independen terhadap variabel dependen, yaitu :

Konstanta $\alpha$ sebesar -0.978403 menyatakan bahwa jika nilai dari Pertumbuhan penjualan $\left(\mathrm{X}_{1}\right)$, Ukuran perusahaan $\left(\mathrm{X}_{2}\right)$, Struktur aset $\left(\mathrm{X}_{3}\right)$ dan profitabilitas $\left(\mathrm{X}_{4}\right)$. adalah kostan (0) maka besar struktur modal adalah sebesar -0.978403 .

Nilai koefisien regresi $X_{1}$ memiliki hubungan positif untuk Pertumbuhan penjualan, artinya setiap perubahan 1 nilai Pertumbuhan penjualan maka struktur modal akan mengalami kenaikan 0.001068 satuan, faktor lain dianggap tetap.

Nilai koefisien regresi $\mathrm{X}_{2}$ memiliki hubungan positif 0.104564 untuk Ukuran perusahaan, artinya setiap perubahan 1 nilai Ukuran perusahaan maka struktur modal akan mengalami kenaikan sebesar 0.104564 satuan, faktor lain dianggap tetap.

Nilai koefisien regresi $\mathrm{X}_{3}$ memiliki hubungan positif 0.009012 untuk Struktur aset, artinya setiap perubahan 1 nilai Struktur aset maka struktur modal akan mengalami kenaikan sebesar 0.009012 satuan, faktor lain dianggap tetap.

Nilai koefisien regresi $\mathrm{X}_{4}$ memiliki hubungan negative 0.006769 untuk Profitabilitas, artinya setiap perubahan 1 nilai Profitabilitas maka struktur modal akan mengalami penurunan sebesar 0.006769 satuan, faktor lain dianggap tetap.

\subsubsection{Uji Hipotesis}

Pengujian hipotesis, peneliti akan menyajikan kembali tabel 4.9 tentang hasil analisis regresi model Model Effect yang telah dinyatakan bahwa model tersebut lebih tepat untuk penelitian ini.

Tabel 12. Hasil Uji Hipotesis

Dependent Variable: $Y$ ?

Method: Panel EGLS (Cross-section random effects)

Date: 08/09/17 Time: 12:01

Sample: 20122015

Included observations: 4

Cross-sections included: 35

Total pool (balanced) observations: 140

Swamy and Arora estimator of component variances

\begin{tabular}{lllll}
\hline \hline Variable & Coefficient & Std. Error & t-Statistic & Prob. \\
\hline \hline C & -0.978403 & 0.709797 & -1.378425 & 0.1704 \\
X1? & 0.001068 & 0.000858 & 1.245789 & 0.2150 \\
X2? & 0.104564 & 0.046329 & 2.257004 & 0.0256 \\
X3? & 0.009012 & 0.002224 & 4.052600 & 0.0001 \\
X4? & -0.006769 & 0.003894 & -1.738255 & 0.0844 \\
\hline \hline & Effects Specification & & \\
& & & S.D. & Rho \\
\hline \hline & & & 0.516636 & 0.8045 \\
Cross-section random & & & 0.254703 & 0.1955 \\
\hline \hline
\end{tabular}




\begin{tabular}{llll}
\multicolumn{4}{l}{ Weighted Statistics } \\
\hline \hline R-squared & 0.151141 & Mean dependent var & 0.192530 \\
Adjusted R-squared & 0.125990 & S.D. dependent var & 0.274989 \\
S.E. of regression & 0.257083 & Sum squared resid & 8.922393 \\
F-statistic & 6.009253 & Durbin-Watson stat & 1.672040 \\
Prob(F-statistic) & 0.000176 & & \\
\hline \hline & Unweighted Statistics & \\
\hline \hline R-squared & 0.127982 & Mean dependent var & 0.804429 \\
Sum squared resid & 46.57470 & Durbin-Watson stat & 1.320315 \\
\hline \hline
\end{tabular}

Sumber : Data diolah dengan E views

Berdasarkan uji model Chow-test menunjukkan bahwa Fixed Effect Model yang dipilih. Di sisi lain, hasil dari uji model Hausman menunjukkan bahwa Random Effect Model yang dipilih dan hasil dari uji model Lagrange Multiplier menunjukkan bahwa Random Effect dipilih. Hasil tersebut terbukti model panel yang dipilih adalah model Random Effect Model.

1) Pengujian secara Parsial ( Uji t )

a. Hipotesis Pertama $\left(\mathrm{H}_{1}\right)$

Uji t dapat dilihat dari hasil pengujian signifikansi regresi parsial. Hasil dapat dilihat dari tabel 12 bahwa nilai signifikansi t-statistic sebesar $0.2150>0,05$. Maka hasil tersebut menyatakan H1 ditolak, berarti tingkat Pertumbuhan penjualan $\left(\mathrm{X}_{1}\right)$ secara parsial tidak berpengaruh terhadap struktur modal (Y). Maka hipotesis $\mathrm{H}_{1}$ tidak terbukti.

b. Hipotesis Kedua $\left(\mathrm{H}_{2}\right)$

Uji t dapat dilihat dari hasil pengujian signifikansi regresi parsial. Hasil dapat dilihat dari tabel 12 bahwa nilai signifikansi t-statistic sebesar $0.0256<0,05$. Maka hasil tersebut menyatakan $\mathrm{H}_{2}$ diterima, berarti Ukuran perusahaan $\left(\mathrm{X}_{2}\right)$ secara parsial berpengaruh terhadap struktur modal (Y). Maka hipotesis $\mathrm{H}_{2}$ terbukti.

c. Hipotesis Ketiga $\left(\mathrm{H}_{3}\right)$

Uji t dapat dilihat dari hasil pengujian signifikansi regresi parsial. Hasil dapat dilihat dari tabel 12 bahwa nilai signifikansi t-statistic sebesar $0.0001<0,05$. Maka hasil tersebut menyatakan $\mathrm{H}_{3}$ diterima, berarti Struktur aset $\left(\mathrm{X}_{3}\right)$ secara parsial berpengaruh terhadap struktur modal (Y). Maka hipotesis $\mathrm{H}_{3}$ terbukti.

d. Hipotesis Ketiga $\left(\mathrm{H}_{4}\right)$

Uji t dapat dilihat dari hasil pengujian signifikansi regresi parsial. Hasil dapat dilihat dari tabel 12 bahwa nilai signifikansi t-statistic sebesar $0.0844>0,05$. Maka hasil tersebut menyatakan $\mathrm{H}_{4}$ ditolak, berarti Profitabilitas $\left(\mathrm{X}_{3}\right)$ secara parsial tidak berpengaruh terhadap struktur modal (Y). Maka hipotesis H4 tidak terbukti.

2) Pengujian secara Simultan (Uji F)

Uji $\mathrm{F}$ dapat dilihat dari hasil pengujian signifikansi regresi simultan. Hasil dapat dilihat pada tabel 12 bahwa nilai F-statistic sebesar 6.009253 dengan nilai signifikansi sebesar $0.000176<0,05$. Berdasarkan hasil tersebut maka 
hipotesis H5 yang menyatakan bahwa tingkat pertumbuhan penjualan, ukuran perusahaan, struktur aset dan profitabilitas secara simultan berpengaruh terhadap struktur modal (Y) di terima. Maka hipotesis H5 terbukti berpengaruh.

3) Koefisien Determinasi $\left(\mathrm{R}^{2}\right)$

Berdasarkan tabel 12 vmenyatakan bahwa nlai Adjusted $R$-square sebesar 0.125990 , artinya besarnya koefisien determinasi penelitian ini sebesar 0.125990 hal ini menyatakn bahwa variabel independen mampu menjelaskan variabel dependen hanya sebesar $12,59 \%$. Sisanya $87,41 \%$ dipengaruhi oleh variabel independen lainnya yang tidak diteliti didalam penelitian ini.

\subsection{Interpretasi Hasil Penelitian asil Pengujian Hipotesis}

\subsubsection{Pengaruh Pertumbuhan penjualan Terhadap struktur modal}

Hasil analisis menyatakan bahwa nilai signifikansi t-statistic dari tingkat Pertumbuhan penjualan $\left(\mathrm{X}_{1}\right)$ sebesar $0.2150>0,05$. Hal ini menyatakan bahwa variabel Pertumbuhan penjualan tidak berpengaruh terhadap struktur modal. Semakin meningkatnya pertumbuhan perusahaan khususnya adanya pertumbuhan penjualan menyebabkan perusahaan membutuhkan penambahan modal. Sedangkan para kreditur dalam memberikan pinjaman cenderung melihat pertumbuhan perusahaan sebagai pertimbangannya. Semakin tinggi tingkat pertumbuhan perusahaan maka semakin mudah bagi perusahaan mendapatkan dana dalam bentuk hutang.

\subsubsection{Pengaruh Ukuran perusahaan Terhadap struktur modal}

Hasil analisis menyatakan bahwa nilai signifikansi t-statistic dari ukuran perusahaan $\left(\mathrm{X}_{2}\right)$ sebesar $0.0256<0,05$. Hal ini menyatakan bahwa variabel Ukuran perusahaan berpengaruh terhadap struktur modal. Perusahaan yang memiliki ukuran besar cenderung tidak menggunakan utang karena perusahaan dengan ukuran besar telah memiliki total aset yang besar dalam melunasi total utangnya. Perusahaan-perusahaan yang memiliki ukuran kecil tidak memiliki banyak pilihan untuk meningkatkan ukuran perusahaannya. Dalam hal ini, perusahaan kecil tidak mempunyai pilihan pendanaan selain mengandalkan pinjaman bank (utang). Sesuai dengan trade off theory bahwa perusahaan kecil dituntut meningkatkan utang agar dapat memanfaatkan besaran utang menjadi pendapatan untuk meningkatkan total aset perusahaan.

\subsubsection{Pengaruh Struktur aset Terhadap struktur modal}

Hasil analisis menyatakan bahwa nilai signifikansi t-statistic dari Struktur aset $\left(\mathrm{X}_{3}\right)$ sebesar $0.0001<0,05$. Hal ini menyatakan bahwa variabel struktur aset berpengaruh terhadap struktur modal. Nilai koefisien struktur aset yang positif menunjukkan semakin tinggi struktur modal maka akan diikuti semakin tinggi nilai struktur modal perusahaan. Hasil penelitian ini sejalan dengan teori yang dikemukakan Sartono (2010:248) menyatakan bahwa perusahaan yang memiliki asset tetap dalam jumlah besar dapat menggunakan utang dalam jumlah besar hal ini disebabkan karena dari skalanya perusahaan besar akan mudah mendapatkan akses ke sumber dana dibandingkan dengan perusahaan kecil. Kemudian besarnya asset tetap dapat digunakan sebagai jaminan utang perusahaan. 


\subsubsection{Pengaruh Profitabilitas Terhadap struktur modal}

Hasil analisis menyatakan bahwa nilai signifikansi t-statistic dari Profitabilitas $\left(\mathrm{X}_{4}\right)$ sebesar $0.0844>0,05$. Hal ini menyatakan bahwa variabel Profitabilitas tidak berpengaruh terhadap struktur modal. Hasil penelitian ini sesuai dengan teoritrade off yang dikemukakan oleh Brealey dkk (2008:25) yang menyatakan bahwa laba yang tinggi seharusnya lebih banyak kapasitas pelayanan utang dan lebih banyak laba kena pajak yang terlindungi oleh karena itu harus memberikan rasio utang yang lebih tinggi. Artinya perusahaan akan menggunakan lebih banyak utang untuk mendapatkan keuntungan yang lebih besar. Hubungan negatif tersebut menunjukkan bahwa jika variabel profitability mengalami kenaikan, maka akan menyebabkan penurunan pada variabel struktur modal. Sesuai dengan pecking order theory bahwa perusahaan dengan tingkat profitabilitas yang tinggi cenderung tidak meningkatkan penggunaan struktur modal. Perusahaan lebih cenderung memakai dana internal dalam memenuhi kebutuhannya.

\subsubsection{Pengaruh Pertumbuhan penjualan, Ukuran perusahaan, Struktur aset Dan profitabilitas Secara Simultan Terhadap struktur modal}

Hasil analisis menyatakan bahwa nilai signifikansi $F$-statistic dari analisis regresi model Random Effect sebesar $0.000176<0,05$. Hal ini menyatakan bahwa variabel pertumbuhan penjualan, ukuran perusahaan, struktur aset dan profitabilitas secara simultan berpengaruh terhadap struktur modal. Variabel ini memiliki pengaruh terhadap struktur modal sebesar $12,59 \%$. Sehingga dapat dijadikan sebagai salah satu pedoman bagi invsetor dalam mengambil keputuan untuk berinvestasi.

\section{SIMPULAN DAN SARAN}

5.1. Simpulan

Berdasarkan hasil penelitian dan pembahasan, dapat disimpulkan hal sebagai berikut :

1) Pertumbuhan penjualan berpengaruh tidak signifikan terhadap struktur modal pada perusahaan manufaktur yang terdaftar di BEI periode tahun 2012-2015.

2) Ukuran perusahaan berpengaruh signifikan terhadap struktur modal pada perusahaan manufaktur yang terdaftar di BEI periode tahun 2012-2015, dengan nilai signifikansi t-statistic sebesar $0.0256<0,05$.

3) Struktur aset berpengaruh signifikan terhadap struktur modal pada perusahaan manufaktur yang terdaftar di BEI periode tahun 2012-2015

4) Profitabilitas berpengaruh tidak signifikan terhadap struktur modal pada perusahaan manufaktur yang terdaftar di BEI periode tahun 2012-2015,

5) Berdasarkan hasil pengujian hipotesis secara simultan bahwa pertumbuhan penjualan, ukuran perusahaan, struktur aset dan profitabilitas secara simultan berpengaruh terhadap struktur modal pada perusahaan manufaktur yang terdaftar di BEI periode tahun 2012-2015artinya hipotesis terbukti berpengaruh.

\subsection{Saran}


Perusahaan hendaknya menjadikan pertumbuhan penjualan, ukuran perusahaan, profitabilitas, struktur aset dan struktur modal sebagai faktor penentu dalam menentukan komposisi struktur modal yang tepat bagi perusahaan 


\section{DAFTAR PUSTAKA}

Agnes Sawir, 2011, Analisa Kinerja Keuangan dan Perencanaan keauangan Perusahaan, PT. Gramedia Pustaka Utama

Agus Sartono, 2010, Manajemen Keuangan Teori dan Aplikasi (4 th ed.). Yogyakarta: BPFE

Albulena Shala. 2014. The Factors that Determine the Capital Structure among Insurance Companies in Kosovo: Empirical Analysis. E-ISSN 2281-4612 ISSN 2281-3993 Academic Journal of Interdisciplinary Studies MCSER Publishing, Rome-Italy Vol 3 No 2 June 2014

Bambang Riyanto, 2012, Dasar-Dasar Pembelanjaan Perusahan Edisi Revisi. BPFE:Yogyakarta

Basu Swastha, 2011, Manajemen Pemasaran Modern. Yogyakarta: Liberty.

Brigham dan Houston, 2010, Dasar-dasar Manajemen Keuangan, Edisi. Sepuluh, Alih Bahasa Ali Akbar Yulianto, Salemba Empat : Jakarta

Dermawan Sjahrial, 2012,Akuntansi Manajemen, Edisi IJakarta : Mitra Wacana. Media

Erwanti, 2013. Analisis Faktor-Faktor Yang Mempengaruhi Struktur Modal Perusahaan Properti Yang Terdaftar Di Bursa Efek Indonesia (Periode 2006-2010). Jurnal Manajemen.

Eugene F. Brigham dan Joel F. Houston, 2011, Dasar - Dasar Manajemen. Keuangan. Edisi 11. Erlangga. Jakarta

Gitman, Lawrence J., 2012, Priciples of Managerial Finance, , 13 edition, Global Edition, Pearson Eduaction Limited

Irham Fahmi, 2011, Analisis Kinerja Keuangan, Penerbit Alfabeta, Bandung

K. R. Subramanyam., \& John J. Wild, 2012, Analisis Laporan Keuangan (Edisi10, Buku 1). Jakarta: Salemba Empat.

Kasmir, 2011, Analisis Laporan Keuangan: Jakarta : PTRajaGrafindo. Persada

Kasmir, 2012, Manajemen Perbankan. Jakarta : PT. RajaGrafindo Persada

Keown, Arthur J. et al. 2011. Dasar-dasar Manajemen Keuangan Edisi ketujuh.Jakarta: Salemba Empat

Kieso dan Weygandt, 2011, Akuntansi Intermediate, Terjemahan Emil Salim, Jilid 1 Edisi 12. Jakarta: Erlangga

Kuncoro 2012, Metode Riset Untuk Bisnis \& Ekonomi Edisi Revisi, Erlangga, Jakarta

Lukman Syamsudin 2009, Manajemen Keuangan Perusahaan: Konsep Aplikasi dalam Perencanaan, Pengawasan, dan Pengambilan Keputusan. 
Jakarta: PT Raja Grafindo Persada

Lukman Syamsudin, 2012, Manajemen Keuangan Perusahaan. Jakarta: Rajawali Pers

Priyatno 2010, Mandiri Belajar SPSS, Cetakan Ketiga, Yogyakarta: Media Kom

Riduwan dan Kuncoro 2012, Cara Menggunakan dan Memakai Path Analysis, Erlangga, Jakarta

S. Munawir, 2012, Analisa Laporan Keuangan, Edisi Keempat, Cetakan Ketigabelas,. Yogyakarta: Liberty

Sangeetha. 2013. Factors Determining Capital Structure: A Case study of listed companies in Sri Lanka. Research Journal of Finance and Accounting ISSN 2222-1697 (Paper) ISSN 2222-2847 (Online) Vol.4, No.6, 2013

Sansoethan dan Suryono. 2016. Analisis Faktor-Faktor Yang Mempengaruhi Struktur Modal Pada Perusahaan Makanan Dan Minuman. Jurnal Ilmu dan Riset Akuntansi : Volume 5, Nomor 1, Januari 2016 ISSN : 2460-0585

Stice dan Skousen, 2010, Intermediate Accounting, Edisi 16, Salemba Empat, Jakarta

Suad Husnan, 2011, Dasar-dasar Teori Portofolio dan Analisis Sekuritas. Yogyakarta.

Sugiyono 2012, Statistika untuk Penelitian. Bandung: CV Alfabeta.

Sugiyono 2013, Metode Penelitian Bisnis. CV Alfabeta, Bandung.

Syafaruddin Alwi, 2013, Alat-alat Analisis dalam Pembelanjaan, Edisi keempat,. Lembaga Penerbit Andi Offset, Yogyakarta

Ticoalu 2013. Analisis Faktor-Faktor Yang Mempengaruhi Struktur Modal Pada Perusahaan Di Sektor Agriculture Yang Terdaftar Di Bursa Efek Indonesia Periode 2007-2011. Calyptra: Jurnal Ilmiah Mahasiswa Universitas Surabaya Vol.2 No.2 (2013)

Triyono dan Achyani. 2015. Analisis Faktor-Faktor Yang Mempengaruhi Struktur Modal Pada Perusahaan Property Dan Real Estate" DAYA SAING Jurnal Ekonomi Manajemen Sumber Daya Vol. 17, No. 1, Juni 2015

Umar, Husein, 2013 Metodologi Penelitian Untuk Skripsi dan Tesis Bisnis, Jakarta. : PT. Gramedia Pustaka

Usman, Marzuki Singgih Riphat,syahrir, 2012, Pengetahuan Dasar Pasar Modal, Istibat Braker Indonesia

Weston dan Copeland, 2009, Manajemen Keuangan, jilid 1, alih bahasa Jaka Wasana, Kirbrandoko, cetakan ketujuh, Penerbit Erlangga, Jakarta 
Www.jsx.co.id

Yoshendy, Achsani, dan Maulana. 2015. Analisis Faktor-Faktor yang Mempengaruhi Struktur Modal Perusahaan Barang Konsumsi di BEI tahun 2002 - 2011. ISSN 1412 - 3681 Jurnal Bisnis \& Manajemen, 2015, Vol. XVI, No. 1, 47-59 